\title{
PENGARUH HARGA, PROMOSI DAN KUALITAS PELAYANAN TERHADAP KEPUTUSAN PEMBELIAN KONSUMEN PADA KEDAI MAKAN PA'MUR KARAWANG
}

\author{
Oleh : \\ Armahadyani \\ Program Studi Magister Manajemen Fakultas Ekonomi dan Bisnis \\ Universitas Singaperbangsa Karawang \\ Email : armahadyani71@gmail.com
}

\begin{abstract}
ABSTRAK
Penelitian ini bertujuan untuk mengetahui, menganalisis dan menjelaskan: (1) bagaimana harga di Kedai Pa'Mur, (2) bagaimana promosi di Kedai Pa'Mur, (3) bagaimana kualitas pelayanan di Kedai Pa'Mur, (4) bagaimana keputusan pembelian konsumen di Kedai Pa'Mur, (5) korelasi harga denga promosi, (6) korelasi promosi dengan kualitas pelayanan, (7) korelasi harga dengan kualitas pelayanan, (8) pengaruh harga, promosi dan kualitas pelayanan terhadap keputusan pembelian di Kedai Pa'Mur secara parsial dan (9) pengaruh harga, promosi dan kualitas pelayanan terhadap keputusan pembelian di Kedai Pa'Mur secara simultan.

Jenis penelitian yang digunakan dalam penelitian ini adalah survei. Populasi pada penelitian ini adalah konsumen Kedai Pa'Mur. Teknik pengambilan sampel menggunakan metode random sampling dengan jumlah sampel sebanyak 365 orang. Teknik pengumpulan data menggunakan kuesioner yang telah diuji validitas dan reliabilitasnya. Metode yang digunakan dalam penelitian ini adalah metode kuantitatif dengan metode deskriptif dan verifikatif, yaitu: mengumpulkan, menyajikan, menganalisis dan melakukan pengujian hipotesis, serta membuat kesimpulan dan saran dan Teknik analisis data yang digunakan untuk menjawab hipotesis adalah analisis jalur (path).

Berdasarkan hasil analisis penelitian, diperoleh kesimpulan sebagai berikut:

1. Korelasi harga $\left(X_{1}\right)$ dengan promosi $\left(X_{2}\right)$ mempunyai nilai koefisien korelasi (r) sebesar 0,108 dan jika diinterpretasikan dengan keeratan hubungan kedua variabel ini mempunyai tingkat hubungan yang rendah (Sugiyono, $2005: 255$ ) dan searah karena nilainya positif. Meskipun rendah terjadinya hubungan kedua variabel tersebut, tapi hal ini menunjukan bahwa harga berperan sebagai sarana informasi terhadap calon konsumen, informasi tersebut bisa didapat dalam bentuk iklan atau bahkan promo-promo yang dilakukan oleh para penjual untuk menarik calon konsumen.

2. Korelasi promosi $\left(\mathrm{X}_{2}\right)$ dengan kualitas pelayanan $\left(\mathrm{X}_{3}\right)$ mempunyai nilai koefisien korelasi (r) sebesar 0,653 dan jika diinterpretasikan dengan keeratan hubungan kedua variabel ini mempunyai tingkat hubungan yang kuat (Sugiyono, 2005 : 255) dan searah karena nilainya positif. Ini menunjukan bahwa jika promosi yang sering dilakukan, maka kualitas pelayananan pun akan ditingkatkan begitupun sebaliknya dengan meningkatkan kualitas
\end{abstract}


pelayanan maka promosi yang dilakukanpun akan semakin meningkat karena dapat dijadikan sebagai nilai plus untuk menarik calon konsumen.

3. Korelasi harga $\left(X_{1}\right)$ dengan kualitas pelayanan $\left(X_{3}\right)$ mempunyai nilai koefisien korelasi (r) sebesar 0,353 dan jika diinterpretasikan dengan keeratan hubungan kedua variabel ini mempunyai tingkat hubungan yang rendah (Sugiyono, 2005 : 255) dan searah karena nilainya positif. Ini menunjukan bahwa jika harga meningkat maka kualitas pelayanan juga akan meningkat. Sebaliknya jika kualitas pelayanan meningkat maka harga juga akan meningkat.

4. Besarnya pengaruh harga yang secara langsung berpengaruh terhadap keputusan pembelian adalah 56,58\%. Berdasarkan temuan penelitian ini dapat disimpulkan bahwa hipotesis penelitian yang menyatakan "harga berpengaruh secara signifikan terhadap keputusan pembelian" dapat diterima.

5. Besarnya pengaruh promosi yang secara langsung berpengaruh terhadap keputusan pembelian adalah $4,28 \%$. Berdasarkan temuan penelitian ini dapat disimpulkan bahwa hipotesis penelitian yang menyatakan "promosi berpengaruh secara signifikan terhadap keputusan pembelian" dapat diterima.

6. Besarnya pengaruh kualitas pelayanan yang secara langsung berpengaruh terhadap keputusan pembelian adalah 2,07\% . Berdasarkan temuan penelitian ini dapat disimpulkan bahwa hipotesis penelitian yang menyatakan "kualitas pelayanan berkontribusi secara signifikan terhadap keputusan pembelian" dapat diterima.

7. Secara simultan harga $\left(X_{1}\right)$, promosi $\left(X_{2}\right)$, dan kualitas pelayanan $\left(X_{3}\right)$ berpengaruh secara signifikan terhadap keputusan pembelian (Y) sebesar $62,92 \%$. Sisanya yaitu sebesar $37,08 \%$ merupakan pengaruh yang datang dari faktor-faktor lain.

Kata kunci : Harga, Promosi, Kualitas Pelayanan, Keputusan Pembelian.

\begin{abstract}
This research aims to know, analyze and explain: (1) how is the price at Kedai Pa'Mur, (2) how promotion at Kedai Pa'Mur, (3) how the quality of service at Kedai Pa'Mur, (4) (7) correlation of promotion with service quality, (7) price correlation with service quality, (8) price influence, promotion and service quality to purchase decision at Kedai Pa' Partial and (9) influence of price, promotion and quality of service to purchase decision at Kedai Pa'Mur simultaneously.

Type of research used in this research is survey. Population in this research is consumer of Kedai Pa'Mur. The sampling technique used random sampling method with 365 samples. Data collection techniques using questionnaires that have been tested for validity and reliability. The method used in this research is quantitative method with descriptive and verifikatif method, namely: collecting, presenting, analyzing and doing hypothesis testing, and making conclusions and suggestions and data analysis techniques used to answer the hypothesis is path analysis.
\end{abstract}


Based on the results of the research analysis, the following conclusions are obtained:

1. The correlation of price (X1) with promotion (X2) has correlation coefficient (r) value of 0.108 and if interpreted by the closeness of the relationship of these two variables have a low level of relationship (Sugiyono, 2005: 255) and in the direction of positive value. Despite the low relation between the two variables, this shows that the price serves as a means of information to potential customers, the information can be obtained in the form of advertisements or even promos by the sellers to attract potential customers.

2. The correlation of promotion (X2) with service quality (X3) has a correlation coefficient value (r) of 0.653 and if interpreted by the closeness of the relationship of these two variables have a strong relationship level (Sugiyono, 2005: 255) and unidirectional because the value is positive. This shows that if the promotion is often done, then the quality of service will be improved vice versa by improving the quality of service then the promotion will be increased as it can be used as a plus to attract potential customers.

3. Price correlation (X1) with service quality (X3) has correlation coefficient (r) value of 0.353 and if interpreted with the closeness of relationship of these two variables have a low level of relationship (Sugiyono, 2005: 255) and unidirectional because the value is positive. This shows that if the price increases then the quality of service will also increase. Conversely, if the quality of service increases then the price will also increase.

4. The magnitude of the influence of prices that directly affect the purchase decision is 56.58\%. Based on the findings of this study can be concluded that the research hypothesis stating "the price significantly influence the purchase decision" is acceptable.

5. The magnitude of promotion that directly affect the purchase decision is 4.28\%. Based on the findings of this study can be concluded that the research hypothesis that states "promotion significantly influence on purchase decisions" is acceptable.

6. The magnitude of the influence of service quality which directly affects the purchase decision is $2.07 \%$. Based on the findings of this study it can be concluded that the research hypothesis which states "service quality contribute significantly to the purchase decision" is acceptable.

7. Simultaneously the price (X1), promotion (X2), and service quality (X3) significantly influence the purchase decision $(Y)$ of $62.92 \%$. The remaining $37.08 \%$ is the effect that comes from other factors.

Keywords : Price, Promotion, Service Quality, Purchase Decision 



\section{PENDAHULUAN}

Perkembangan zaman yang terus maju saat ini, menuntut para pengusaha lebih aktif lagi dalam melakukan strategi ataupun perhitungan agar mampu bersaing di pasaran agar tidak ditinggalkan oleh konsumen. Dengan diberlakukannya MEA (Masyarakat Ekonomi Asean) sekarang ini dimana perekonomian secara makro Indonesia tidak stabil membuat pengusaha semakin terpojok manakala tidak cepat bergerak mengambil tindakan untuk berusaha bangkit. Karena persaingan bisnis yang terjadi saat ini disemua sektor, salah satunya adalah sektor kuliner. Ragam macam usaha kuliner mulai dari skala kecil seperti pedagang kaki lima dan warung makan hingga usaha kuliner skala besar seperti rumah makan, cafe, dan restoran kini semakin banyak dan beragam bak cendawan di musim hujan.

Salah satu usaha kuliner yang juga banyak dilirik oleh pelaku bisnis saat ini adalah usaha kuliner khas daerah, mengingat negara ini segudang menu kuliner yang dilupakan karena moderenisasi dalam dunia kuliner. Kini, kuliner khas daerah tidak hanya dapat dijumpai di warung makan kaki lima saja namun kini kuliner khas daerah juga banyak kita temukan di restoran dan hotel bintang lima dengan berbagai macam menu yang beraneka macam. Fenomena semakin banyaknya pelaku bisnis kuliner ini berdampak juga di Kabupaten Karawang.

Berikut ini grafik 1.1 yang menggambarkan perkembangan cafée, restoran, rumah makan, dan pondok wisata di Kota Karawang.

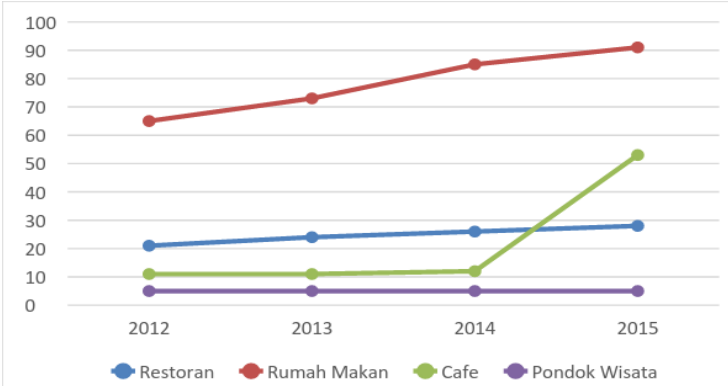

Sumber: www.karawangkab.go.id

Berdasarkan grafik 1.1 jumlah rumah makan yang ada di Kabupaten Karawang lebih tinggi dibandingkan Restoran, Café, dan Pondok Wisata. Jumlah tersebut akan terus bertambah karena saat ini banyak pembuatan bangunan baru yang nantinya akan dijadikan restoran dan rumah makan. Fenomena ini dapat terlihat dari banyaknya rumah makan di Karawang yang menjadikan persaingan di industri kuliner semakin ketat. Persaingan diantara pelaku bisnis kuliner dituntut untuk memenuhi setiap kebutuhan konsumen dan dapat menarik perhatian konsumen agar dapat menggunakan produknya. Produsen berlomba-lomba bersaing melakukan inovasi untuk membuat produk andalan yang benar-benar diminati oleh konsumen.

Salah satu usaha kuliner yang bersaing melakukan inovasi tersebut adalah Kedai Makan Pa'Mur (Padang - Jamur) yang berlokasi di area outlet oleh-oleh khas Karawang Jalan Tarumanagara (Interchange) Karawang Barat- Karawang. Kedai Makan Pa'Mur merupakan kedai dengan perpaduan menu masakan khas daerah Padang dan menu aneka olahan Jamur khas Karawang. Kedai Makan Pa'Mur merupakan salah satu kedai yang menyajikan makanan tradisional khas dua daerah yaitu Karawang dan Padang. Kedai Makan pa'Mur mulai beroperasi 
pada tanggal 23 Oktober 2014 dan merupakan kedai yang mengedepankan konsep makanan khas daerah menyehatkan. Dalam persaingan di industri kuliner ini, sebuah usaha kuliner dituntut untuk menawarkan kualitas pelayanan, harga dan promosi yang baik agar menimbulkan minat beli konsumen. Hal ini dapat dilihat pada gambar dibawah ini mengenai Survei dari 30 responden tentang data penilaian konsumen di Kedai Makan Pa'Mur.

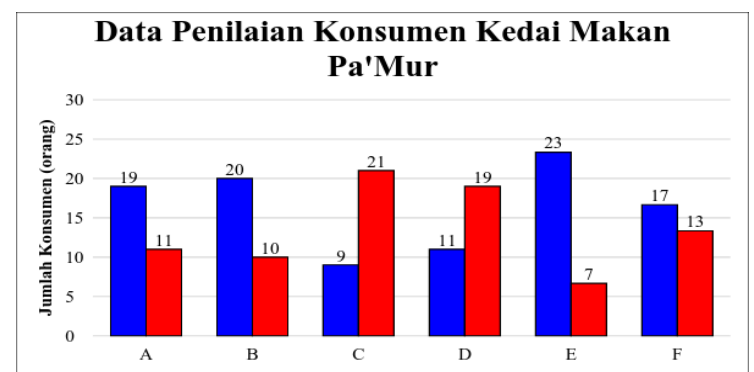

Berikut ini terdapat data pengunjung yang melakukan pembelian di kedai makan Pa'Mur disajikan dalam bentuk Tabel :

\section{Tabel 1.1}

\section{Kunjungan Konsumen Kedai Makan Pa'Mur Periode Juli-Desember 2016}

\begin{tabular}{|c|l|r|r|}
\hline NO & BULAN & JUMLAH PENGUNJUNG & PERSENTASE \\
\hline 1 & Juli & 988 & $27 \%$ \\
\hline 2 & Agustus & 546 & $15 \%$ \\
\hline 3 & September & 468 & $13 \%$ \\
\hline 4 & Oktober & 884 & $24 \%$ \\
\hline 5 & November & 494 & $13 \%$ \\
\hline 6 & Desember & 286 & $8 \%$ \\
\hline \multicolumn{2}{|c|}{ JUMLAH } & $\mathbf{3 , 6 6 6}$ & $\mathbf{1 0 0 \%}$ \\
\hline
\end{tabular}

Sumber : Kedai Pa'Mur 2016

Berdasarkan hasil survei data tahun 2016 yang didapatkan oleh penulis dilapangan yang ditunjukkan pada tabel 1.1 yaitu adanya penurunan kunjungan konsumen sebesar $5 \%$ pada bulan Desember. Meskipun tingkat kunjungan dari bulan Juli sampai dengan bulan Desember 2016 turun, namun tidak menunjukkan penurunan yang signifikan. Pihak manajemen mengharapkan dan menargetkan adanya tingkat kunjungan konsumen di Kedai makan Pa'Mur harus selalu mengalami kenaikan yang signifikan dari setiap bulannya guna mencapai omset yang optimal.

Konsumen merupakan suatu bagian terpenting bagi keberlangsungan suatu usaha. Kedai Makan Pa'Mur memiliki pesaing yang banyak di jenis usaha yang kuliner. Dalam rangka meningkatkan jumlah pembelian yang dilakukan konsumen di Kedai Makan Pa'Mur, maka pihak manajemen melakukan strategi pemasaran melalui strategi produk.

Kualitas pelayanan harus dijaga oleh setiap produsen agar konsumen yang telah membeli atau menggunakan produknya akan tetap setia terhadap kedai $\mathrm{Pa}$ 'Mur tersebut sehingga tidak berpindah ke kedai yang lain. Keistimewaan atau keunggulan kualitas pelayanan dapat diukur melalui tingkat kepuasan pelanggan keistimewaan ini tidak hanya terdiri dari karakteristik produk yang ditawarkan, 
tetapi juga pelayanan yang menyertai produk itu sendiri seperti: cara pemasaran, cara pembayaran ketepatan penyerahan dan lain-lain. Kualitas pelayanan memiliki delapan dimensi yang menentukan karakteristik produk tersebut yaitu Performance, features, Conformance to Specification, Reliability, Durability, Serviceability, Estetika, Perceived Quality. (Fandy Tjiptono, 2008:68). Menurut Kotler (2005 : 84) Kualitas pelayanan adalah kemampuan suatu pelayanan untuk memberikan hasil / kinerja yang sesuai atau melebihi dari apa yang diinginkan pelanggan. Semakin baik kualitas pelayanan yang di tawarkan oleh Kedai Pa'Mur maka akan meningkatkan minat pembelian yang dilakukan konsumen untuk kembali lagi memilih menu makanan khas Padang dan Karawang yang terdapat di Kedai Pa'Mur.

Untuk meningkatkan keputusan pembelian konsumen di Kedai Pa'Mur, selain menjaga dan meningkatkan kualitas dari pelayanan, harga yang ditawarkan pun sangatlah beragam dan terjangkau, dengan harga yang beraneka ragam tersebut, jelas terlihat bahwa Kedai Pa'Mur ingin selalu mencoba mempertahankan konsumen dengan cara memberikan harga yang sesuai dengan keinginan dan kebutuhan konsumen. Karena keputusan pembelian adalah suatu keputusan seseorang dimana dia memilih salah satu dari beberapa alternatif pilihan yang ada dan proses integrasi yang mengkombinasi sikap pengetahuan untuk mengevaluasi dua atau lebih perilaku alternatif dan memilih salah satu diantaranya.

Harga merupakan inti dari semua kegiatan pemasaran yang dapat menghasilkan laba atau kerugian. Keputusan suatu harga dapat terlaksana dengan baik apabila pemasar memiliki informasi sikap, perilaku konsumen serta informasi detail mengenai pesaing sehingga penentuan harga pasar dapat ditetapkan secara tepat. Dari sudut pandang pemasaran, harga merupakan satuan moneter atau ukuran lainnya yang ditukarkan agar memperoleh hak kepemilikan atau penggunaan suatu barang atau jasa. Menurut Tjiptono (2008:465) harga adalah jumlah uang (satuan moneter) dan atau aspek lain (non moneter) yang mengandung utilitas/kegunaan tertentu yang diperlukan untuk mendapatkan suatu produk.

Dari uraian diatas penulis tertarik untuk melakukan penelitian mengenai keputusan pembelian konsumen di Kedai Pa'Mur Karawang. Dimana aspek Kualitas Produk, promosi dan Harga yang akan diteliti. Sehingga penelitian ini mengambil judul "Pengaruh Harga, Promosi dan Kualitas Pelayanan Terhadap Keputusan Pembelian Konsumen Pada Kedai Makan Pa'Mur”.

\section{TINJAUAN PUSTAKA \\ Manajemen}

Manajemen bukan merupakan istilah asing pada masa sekarang. Istilah manajemen berasal dari Bahasa Inggris yaitu "To Manage" yang berarti memimpin atau mengelola suatu aktivitas sekelompok manusia untuk mencapai sasaran yang sebenarnya sudah ditetapkan secara menyeluruh. Oleh karena itu bila dilihat dari segi perusahaan, sukses atau tidaknya suatu perusahaan dalam mencapai tujuannya, sangat tergantung kepada pelaksanaan dan pengelolaan manajemen perusahaantersebut.

Menurut James A.F. Stoner dalam buku Handoko (2009 : 8) :

"Manajemen adalah proses perencanaan, pengorganisasian, pengarahan, dan pengawasan usaha-usaha para anggota organisasi dan penggunaan sumber 
daya-sumber daya organisasi lainnya agar mencapai tujuan organisasi yang telah ditetapkan".

Menurut Marry Parker Follet dalam buku Handoko (2009 : 8) :

"Manajemen sebagai seni dalam menyelesaikan pekerjaan melalui orang lain".

Menurut Hasibuan (2007 : 2) :

"Manajemen adalah ilmu dan seni mengatur proses pemanfaatan sumberdaya manusia dan sumber-sumber lainnya secara efektif dan efisien untuk mencapai suatu tujuan tertentu".

Sedangkan Menurut Bernardine R. Wirjana (2007:11) definisi manajemen sebagai berikut :

"Manajemen adalah suatu proses dimana orang-orang yang bertanggung jawab dalam suatu organisasi, menyelesaikan tugas-tugas melalui upayaupaya orang lain dalam kegiatan kelompok"

Dari beberapa definisi diatas dapat diartikan bahwa manajemen adalah alat untuk mengontrol dan mengendalikan kegiatan perusahaan dengan memanfaatkan orang lain dalam pencapaian tujuan tersebut, maka orang-orang dalam organisasi harus jelas wewenang, tugas dan tanggung jawab pekerjaannya.

\section{Pemasaran}

Pemasaran menjadi bagian yang sangat penting bagi setiap perusahaan untuk mempertahankan keberlangsungan usaha dan memiliki peranan dalam memuaskan kebutuhan pelanggan dan keinginan konsumen dengan penyediaan produk melalui perencanaan serta penyerahan produk agar dapat dikonsumsi oleh konsumen.

Menurut Miller \& Layton (2000), dalam Fandy Tjiptono (2005:2) bahwa :

"Pemasaran merupakan sistem total aktivitas bisnis yang dirancang untuk merencanakan, menetapkan harga, mempromosikan dan mendistribusikan produk, jasa, dan gagasan yang mampu memuaskan keinginan pasar sasaran dalam rangka mencapai tujuan organisasional."

Menurut Philip Kotler (2008), dalam Danang Sunyoto(2012:18) bahwa :

"Marketing is asocial and managerial process by which individuals and groups obtain what they need and what through creating, offering, and exchanging products of value of wiht other (pemasaran adalah proses sosial dan manajerial dengan mana seseorang atau kelompok memperoleh apa yang mereka butuhkan dan inginkan melalui penciptaan dan pertukaran peroduk dan nilai).”

Dari buku Elements of marketing yang ditulis oleh Paul D. Converse. Harvey W. Huege, and Robert V. Mitchell. dalam buku Buchari Alma (2011:2) bahwa :

"Marketing has been defined as the business of buying and selling, and as including those business activities involved in the flow of goods and services between producers and customers".

Berdasarkan definisi pengertian diatas maka dapat disimpulkan bahwa pemasaran adalah merupakan suatu proses sosial dan manajerial, baik pada individu dan kelompok untuk memenuhi kebutuhan dan keinginan melalui 
penciptaan, penawaran dan pertukaran nilai produk dengan yang lain. Dan pemasaran merupakan upaya menciptakan loyalitas konsumen terhadap produk yang ditawarkan.

\section{Manajemen Pemasaran}

Pengertian manajemen pemasaran menurut Buchari Alma (2004:130) yaitu:

"Manajemen Pemasaran adalah merencanakan, pengarahan, dan pengawasan seluruh kegiatan pemasaran perusahaan ataupun bagian dipemasaran."

Pengertian manajemen pemasaran menurut Lupiyo Adi (2006:6) bahwa :

"Manajemen pemasaran adalah suatu analisis, perencana, pelaksanaan serta kontrol program-program yang telah direncanakan dalam hubungannya dengan pertukaran-pertukaran yang diinginkan terhadap konsumen yang dituju untuk memperoleh keuntungan pribadi maupun bersama."

Kotler dan kevin lene keller (2009:05) mengungkapkan bahwa :

"Manajemen pemasaran adalah seni dan ilmu memilih pasar sasaran dan meraih, mempertahan, serta menumbuhkan pelanggan dengan menciptakan, menghantarkan, dan mengomunikasikan nilai pelanggan yang unggul"

Dari uraian di atas dapat dikatakan bahwa manajemen pemasaran tidak hanya berfungsi untuk menentukan dan meningkatkan permintaan di pasar, tetapi juga merubah dan mengurangi permintaan tersebut dengan cara menciptakan dan mengkomunikasikan nilai konsumen. Jadi manajemen pemasaran berusaha mengatur tingkat, waktu dan susunan dari permintaan yang ada, agar dapat membantu organisasi mencapai sasarannya.

\section{Harga}

Harga merupakan satu-satunya unsur bauran pemasaran yang memberikan pemasukan atau pendapatan bagi perusahaan, sedangkan ketiga unsur lainnya (produk, distribusi, dan promosi) menyebabkan timbulnya biaya (pengeluaran). Di samping itu harga merupakan unsur bauran pemasaran yang bersifat fleksibel, artinya dapat diubah dengan cepat (Tjiptono, 2008). Dari sudut pandang pemasaran, harga merupakan satuan moneter atau ukuran lainnya (termasuk barang dan jasa lainnya) yang ditukarkan agar memperoleh hak kepemilikan atau penggunaan suatu barang atau jasa (Tjiptono, 2008).

Harga menurut Kotler \& Armstrong (2008) adalah jumlah uang yang ditagihkan atas suatu produk atau jasa. Lebih luas lagi, harga adalah jumlah semua nilai yang diberikan oleh pelanggan untuk mendapatkan keuntungan dari memiliki atau menggunakan suatu produk atau jasa.

\section{Faktor-faktor Yang Mempengaruhi Penetapan Harga}

Menurut Stanton (2004), beberapa faktor yang biasanya mempengaruhi keputusan penetapan harga, antara lain :

1. Permintaan produk

2. Target pangsa pasar

3. Reaksi pasar

4. Penetrasi rantai saringan

5. Produk, saluran distribusi dan promosi 


\section{Biaya produksi}

\section{Peranan Harga}

Harga memiliki dua peranan utama dalam proses pengambilan keputusan para pembeli, yaitu peranan alokasi dan peranan informasi (Tjiptono, 2008) :

1. Peranan alokasi dari harga yaitu fungsi harga dalam membantu para pembeli untuk memutuskan cara memperoleh manfaat atau utilitas tertinggi yang diharapkan berdasarkan daya belinya. Dengan demikian, adanya harga dapat membantu para pembeli untuk memutuskan cara mengalokasikan daya belinya pada berbagai jenis barang dan jasa. Pembeli membandingkan harga dari berbagai alternatif yang tersedia, kemudian memutuskan alokasi dana yang dikehendaki.

2. Peranan informasi dari harga

yaitu fungsi harga dalam 'mendidik' konsumen mengenai faktor-faktor produk, seperti kualitas. Hal ini terutama bermanfaat dalam situasi dimana pembeli mengalami kesulitan untuk menilai faktor produk atau manfaatnya secara objektif. Persepsi yang sering berlaku adalah bahwa harga yang mahal mencerminkan kualitas yang tinggi.

\section{Dimensi dan Indikator Harga}

Menurut Schiffman dan Kanuk (2007, p173) ada dua dimensi harga, yaitu:

1. Harga yang dipersepsikan, indikatornya adalah Keterjangkauan harga, kesesuaian harga dengan prodak yang ditawarkan, kesesuaian harga dengan prodak yang diinginkan, harga sesuai dengan pendapatan.

2. Harga yang direferensikan, indikatornya adalah kesesuaian harga dengan kualitas prodak, kesesuaian harga dengan tempat, kesesuaian harga dengan pelayanan, kesesuaian harga dengan fasilitas,kesesuaian harga dengan menu.

\section{Promosi}

Promosi merupakan salah satu variabel marketing mix yang digunakan oleh perusahaan untuk mengadakan komunikasi dengan pasarnya. Promosi juga sering dikatakan sebagai "proses berlanjut" karena dapat menumbulkan rangkaian kegiatan selanjutnya dari perusahaan.

Menurut Swastha dan Sukotjo (1993) promosi adalah arus informasi atau persuasi satu arah yang dibuat untuk mengarahkan seseorang atau organisasi kepada tindakan yang menyebabkan pertukaran dalam pemasaran.

Sementara Sistaningrum (2002) mengungkapkan arti promosi adalah suatu upaya atau kegiatan perusahaan dalam mempengaruhi konsumen aktual maupun konsumen potensial agar mereka mau melakukan pembelian terhadap produk yang ditawarkan, saat ini atau dimasa yang akan datang.

Adapun tujuan dari pada perusahaan melakukan promosi menurut Tjiptono (2001) adalah menginformasikan (informing), mempengaruhi dan membujuk (persuading) serta mengingatkan (reminding) pelangggan tentang perusahaan dan bauran pemasarannya. Sistaningrum (2002) menjelaskan tujuan promosi adalah empat hal, yaitu memperkenalkan diri, membujuk, modifikasi dan membentuk tingkah laku serta mengingatkan kembali tentang produk dan perusahaan yang bersangkutan.

\section{Dimensi dan Indikator Promosi}


Adapun dimensi dan indikator dalam penelitian ini adalah sebagai berikut (Mursid, 2013) :

1. Iklan, Indikatornya adalah brosur, pamfle, spanduk, poster.

2. Promosi penjualan, indikatornya adalah diskon, undian berhadiah dan gratis prodak.

3. Personal selling, indikatornya adalah bazar dan dor to dor.

4. Publisitas, indikatornya adalah aktif di medsos dan media.

\section{Kualitas Pelayanan}

Kata kualitas mengandung banyak definisi dan makna karena setiap orang akan mengartikannya secara berbeda, seperti kesesuaian dengan persyaratan atau tuntutan, kecocokan, pemakaian perbaikan berkelanjutan, bebas dari kerusakan atau cacat, pemenuhan kebutuhan pelanggan, melakukan segala sesuatu yang membahagiakan. Dalam perspektif TQM (Total Quality Management) kualitas dipandang secara luas, yaitu tidak hanya aspek hasil yang ditekankan, tetapi juga meliputi proses, lingkungan dan manusia. Hal ini jelas tampak dalam definisi yang dirumuskan oleh Goeth dan Davis yang dikutip Tjiptono (2012) bahwa kualitas merupakan suatu kondisi dinamis yang berhubungan dengan produk, jasa, manusia, proses, dan lingkungan yang memenuhi atau melebihi harapan. Menurut Garvin yang dikutip Tjiptono (2012) menyatakan bahwa terdapat lima perspektif mengenai kualitas, salah satunya yaitu bahwa kualitas dilihat tergantung pada orang yang menilainya, sehingga produk yang paling memuaskan preferensi seseorang merupakan produk yang berkualitas paling tinggi.

Pelayanan dapat didefinisikan sebagai segala bentuk kegiatan yang diberikan oleh satu pihak atau lebih kepada pihak lain yang memiliki hubungan dengan tujuan untuk dapat memberikan kepuasan kepada pihak kedua yang bersangkutan atas barang dan jasa yang diberikan. Pelayanan memiliki pengertian yaitu terdapatnya dua unsur atau kelompok orang dimana masing-masing saling membutuhkan dan memiliki keterkaitan, oleh karena itu peranan dan fungsi yang melekat pada masing-masing unsur tersebut berbeda. Hal-hal yang menyangkut tentang pelayanan yaitu faktor manusia yang melayani, alat atau fasilitas yang digunakan untuk memberikan pelayanan, mekanisme kerja yang digunakan dan bahkan sikap masing-masing orang yang memberi pelayanan dan yang dilayani.

Pengertian kualitas pelayanan berpusat pada upaya pemenuhan kebutuhan dan keinginan pelanggan serta ketetapan penyampaiannya untuk mengimbangi harapan pelanggan. Menurut Lewis dan Booms (dalam Tjiptono, 2012) mendefinisikan kualitas pelayanan secara sederhana, yaitu ukuran seberapa bagus tingkat layanan yang diberikan mampu sesuai dengan ekspektasi pelanggan. Artinya kualitas pelayanan ditentukan oleh kemampuan perusahaan atau lembaga tertentu untuk memenuhi kebutuhan yang sesuai dengan apa yang diharapkan atau diinginkan berdasarkan kebutuhan pelanggan. Dengan kata lain, faktor utama yang mempengaruhi kualitas pelayanan adalah pelayanan yang diharapkan pelanggan dan persepsi masyarakat terhadap pelayanan tersebut.

\section{Dimensi dan Indikator Kualitas Pelayanan}

Menurut Fandy Tjiptono (2005) menyatakan bahwa ada lima dimensi pokok yang dapat digunakan untuk mengukur kualitas pelayanan, yaitu:

1. Bukti langsung (Tangibles), indikatornya adalah fasilitas fisik, perlengkapan pegawai dan sarana komunikasi. 
2. Keandalan (Reliability), indikatornya adalah akurat dalm pelayanan dan cepat dalam pelayanan.

3. Daya Tanggap (responsiveness), indikatornya adalah keramahan dan kesigapan.

4. Jaminan (Assurance), indikatornya adalah rasa tanggung jawab dan pengeahuan.

5. Empati (Emphaty), indikatornya adalah perhatian terhadap konsumen dan memahami keinginan konsumen.

\section{Keputusan Pembelian}

Menurut Kotler (2002), keputusan pembelian adalah tindakan dari konsumen untuk mau membeli atau tidak terhadap produk. Dari berbagai faktor yang mempengaruhi konsumen dalam melakukan pembelian suatu produk atau jasa, biasanya konsumen selalu mempertimbangkan kualitas, harga dan produk sudah yang sudah dikenal oleh masyarakat Sebelum konsumen memutuskan untuk membeli, biasanya konsumen melalui beberapa tahap terlebih dahulu yaitu, (1) pengenalan masalah, (2) pencarian informasi. (3) evaluasi alternatif, (4) keputusan membeli atau tidak, (5) perilaku pascapembelian. Pengertian lain tentang Keputusan pembelian menurut Schiffman dan Kanuk (2000: 437) adalah "the selection of an option from two or alternative choice". Dapat diartikan, keputusan pembelian adalah suatu keputusan seseorang dimana dia memilih salah satu dari beberapa alternatif pilihan yang ada.

Menurut Kotler (2009:184) mengemukakan bahwa proses keputusan pembeli terdiri dari lima tahapan. Tahapan pembelian konsumen tersebut antara lain:

1. Pengenalan kebutuhan

2. Pencarian informasi

3. Evaluasi alternatif

4. Keputusan pembelian

5. Perilaku pasca pembelian

\section{Faktor-faktor yang Mempengaruhi Keputusan Pembelian}

Menurut phillip Kotler (2003:202) perilaku pembelian konsumen dipengaruhi oleh empat faktor, diantaranya sebagai berikut:

1. Faktor budaya

2. Faktor sosial

3. Pribadi

4. Psikologi

5.

\section{Dimensi dan Indikator Keputusan Pembelian}




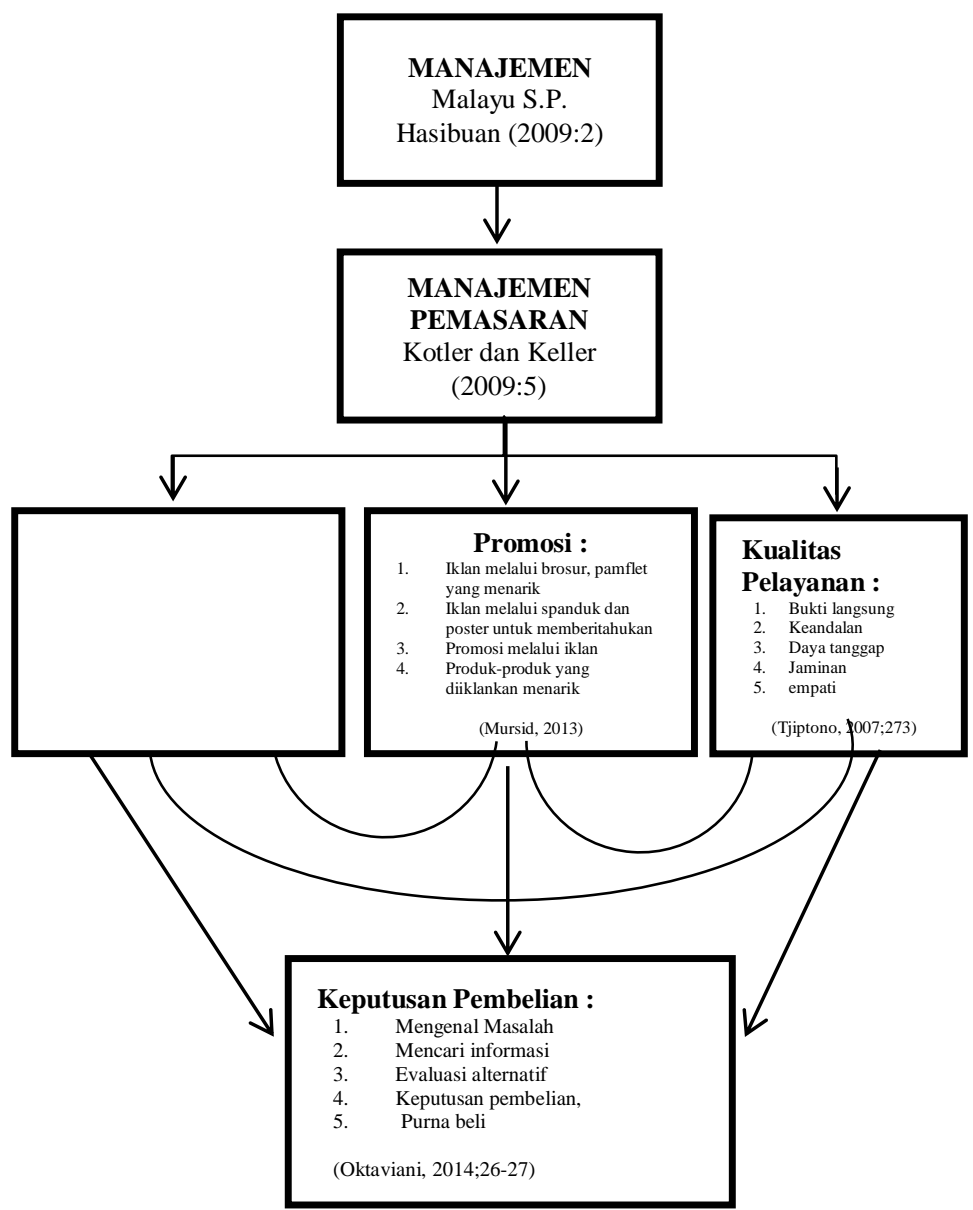

Adapun dimensi dan indikator dalam keputusan pembelian yang dijadikan acuan dalam penelitian ini adalah (Kotler, 2008;184) :

1. Pengenalan Masalah, meliputi/indikatornya adalah kecenderungan calon konsumen dalam melakukan pembelian karena kebutuhan.

2. Mencari informasi, indikatornya adalah sumber pribadi, publik dan pengalaman.

3. Evaluasi alternatif, indikatornya adalah manfaat dan pelayanan jasa

4. Keputusan pembelian, indikatornya adalah merk, lokasi dan kuantitas waktu

5. Purna beli, indikatornya adalah tingkat kepuasan setelah melakukan pembelian.

\section{Kerangka Pemikiran}

Sumber : Peneliti 2017

\section{Gambar 1.1 Kerangka Pikir Penelitian}

\section{Hipotesis Penelitian}

Berdasarkan landasan teori dan kerangka berpikir yang telah diuraikan, dapat disusun beberapa hipotesis penelitian sebagai berikut:

1. Terdapat korelasi antara harga dengan keputusan pembelian pada Kedai Makan Pa'Mur.

2. Terdapat korelasi antara promosi dengan keputusan pembelian pada Kedai Makan Pa'Mur.

3. Terdapat korelasi antara kualitas pelayanan dengan keputusan pembelian pada Kedai Makan Pa'Mur. 
4. Terdapat korelasi antara harga - promosi, promosi - kualitas pelayanan dan harga - kualitas pelayanan pada kedai Makan Pa'Mur

5. Terdapat pengaruh secara parsial antara harga, promosidan kualitas pelayanan terhadap keputusan pembelian pada Kedai Makan Pa'Mur.

6. Terdapat pengaruh secara simultan antara harga, promosi dan kualitas pelayanan terhadap keputusan pembelian pada Kedai Makan Pa'Mur.

\section{METODOLOGI PENELITIAN}

Metode yang digunakan dalam penelitian ini adalah metode kuantitatif, dapat diartikan sebagai metode penelitian yang berlandaskan filsafat positivisme, digunakan untuk meneliti pada populasi atau sampel tertentu, pengumpulan data menggunakan instrumen penelitian, analisis data bersifat kuantitatif/statistik, dengan tujuan untuk menguji hipotesis yang telah ditetapkan (sugiyono:2013:8). Adapun analisisnya menggunakan metode analisis deskriptif dan verifikatif.

\section{Populasi dan sampel}

Populasi dalam penelitian ini adalah jumlah konsumen Kedai Makan Pa'Mur pada bulan Juli - Desember 2016 yang berjumlah 3.666 orang. Dengan jumlah sampel sebanyak 365 orang.

\section{Jenis dan Sumber Data}

Data adalah segala sesuatu yang diketahui atau dianggap mempunyai sifat bias memberikan gambaran tentang suatu keadaan atau persoalan (Supranto, 2001). Data yang digunakan dalam penelitian ini meliputi adalah data Primer. Data primer yang ada dalam penelitian ini merupakan penyebaran kuesioner.

\section{Teknik Pengumpulan Data}

Dalam pengumpulan data ini, peneliti melaksanakan riset secara langsung pada objek penelitian untuk mendapatkan data yang diperlukan guna melengkapi data yang dibutuhkan yaitu dengan cara :
1. Kuesioner
2. Wawancara
3. Studi Pustaka

\section{Uji Keabsahan Data}

Konsep untuk mengukur kualitas data, yaitu validitas dan reliabilitas. Penelitian akan menghasilkan kesimpulan yang tepat jika datanya valid dan reliable. Suatu instrumen yang reliable belum tentu valid, karenanya reliabilitas instrumen merupakan syarat untuk pengujian validitas instrumen. Oleh karena itu instrumen yang valid umumnya reliable, tetapi pengukuran reliabilitas instrumen perlu dilakukan.

Dengan kualitas data yang baik maka data yang terkumpul benar-benar menggambarkan fenomena yang ingin diukur. Sehingga dengan menggunakan instrumen yang valid dan reliable, maka hasil penelitian dapat dipertanggungjawabkan secara ilmiah.

\section{Rancangan Analisis Data}

\section{Analisis Deskriftif}

Analisis deskriptif adalah bagian dari statistik yang digunakan untuk manggambarkan atau mendeskripsikan data tanpa bermaksud mengenaralisir atau membuat kesimpulan tapi hanya menjelaskan kelompok data itu saja, Penulis 
mempelajari buku-buku dan lainnya yang ada hubungannya dengan masalah yang dibahas baik secara langsung maupun tidak langsung.

\section{Rentang Skala}

Dalam penelitian ini untuk menganalisis data hasil survei yang berasal dari hasil pengukuran yaitu dengan menggunakan innstrumen dari skala likert.

Formulasi Analisis Rentan Skala:

$$
\begin{aligned}
& \mathbf{R S}=\frac{\mathbf{n}(\mathbf{m}-\mathbf{1})}{\mathbf{M}} \\
& \text { Dimana }: \mathbf{n}=\text { Jumlah Sampel } \\
& \quad \mathbf{m}=\text { jumlah Alternatif Jawaban (skor }=5 \text { ) } \\
& \quad \text { Sehingga dalam penelitian ini rentang skalanya adalah: }
\end{aligned}
$$

\begin{tabular}{|c|c|c|c|c|c|c|}
\hline \multirow[b]{2}{*}{$\begin{array}{l}\text { Skala } \\
\text { Skor }\end{array}$} & \multirow[b]{2}{*}{$\begin{array}{c}\text { Pernya } \\
\text { taan }\end{array}$} & \multirow[b]{2}{*}{$\begin{array}{c}\text { Rentang } \\
\text { Skala }\end{array}$} & \multicolumn{4}{|c|}{ Deskripsi Skor } \\
\hline & & & Harga & Promosi & \begin{tabular}{|c|} 
Kualitas \\
Pelayanan
\end{tabular} & \begin{tabular}{|l|} 
Keputusan \\
Pembelian
\end{tabular} \\
\hline 1 & $\begin{array}{c}\text { Sangat } \\
\text { Tidak } \\
\text { Setuju/ } \\
\text { Baik }\end{array}$ & $365-657$ & $\begin{array}{l}\text { Sangat } \\
\text { Tidak } \\
\text { Setuju }\end{array}$ & $\begin{array}{l}\text { Sangat } \\
\text { Tidak } \\
\text { Baik }\end{array}$ & $\begin{array}{l}\text { Sangat } \\
\text { Tidak } \\
\text { Baik }\end{array}$ & \begin{tabular}{|l|} 
Sangat \\
Tidak \\
Setuju
\end{tabular} \\
\hline 2 & $\begin{array}{l}\text { Tidak } \\
\text { Setuju/ } \\
\text { Baik }\end{array}$ & $657,1-949$ & $\begin{array}{l}\text { Tidak } \\
\text { Setuju }\end{array}$ & $\begin{array}{l}\text { Tidak } \\
\text { Baik }\end{array}$ & $\begin{array}{l}\text { Tidak } \\
\text { Baik }\end{array}$ & $\begin{array}{l}\text { Tidak } \\
\text { Setuju }\end{array}$ \\
\hline 3 & $\begin{array}{l}\text { Cukup } \\
\text { Setuju/ } \\
\text { Baik }\end{array}$ & $949,1-1.241$ & $\begin{array}{l}\text { Cukup } \\
\text { Setuju }\end{array}$ & $\begin{array}{l}\text { Cukup } \\
\text { Baik }\end{array}$ & $\begin{array}{c}\text { Cukup } \\
\text { Baik }\end{array}$ & $\begin{array}{l}\text { Cukup } \\
\text { Setuju }\end{array}$ \\
\hline 4 & $\begin{array}{l}\text { Setuju/ } \\
\text { Baik }\end{array}$ & $1.241,1-1.533$ & Setuju & Baik & Baik & Setuju \\
\hline 5 & $\begin{array}{l}\text { Sangat } \\
\text { Setuju/ } \\
\text { Baik }\end{array}$ & $1.533,1-1.825$ & $\begin{array}{l}\text { Sangat } \\
\text { Setuju }\end{array}$ & $\begin{array}{l}\text { Sangat } \\
\text { Baik }\end{array}$ & $\begin{array}{c}\text { Sangat } \\
\text { Baik }\end{array}$ & $\begin{array}{l}\text { Sangat } \\
\text { Setuju }\end{array}$ \\
\hline
\end{tabular}

Tabel 2. Analisis Rentang Skala

Sumber: Hasil Analisis 2017

Berdasarkan hasil perhitungan diatas, dapat dinilai rentang skala yang selanjutnya dapat dipakai untuk memprediksi Pengaruh Harga, Promosi dan Kualitas Pelayanan Terhadap keputusanpembelianPada Kedai Makan Jamur. Rentang skala diatas dapat digambarkan melaui Bar Skala atau Bae Scale:

TS/STB/STB/STS TS/TB/TB/TS CS/CB/CB/CS S/B/B/S SS/SB/SB/SS

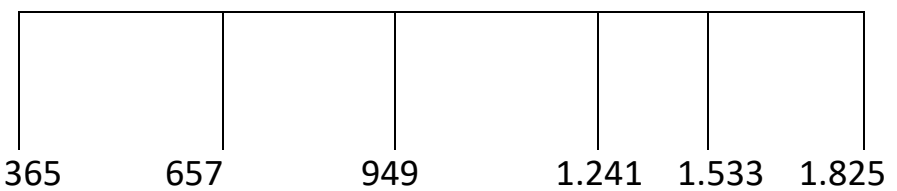

Sumber: Hasil Analisis 2017

\section{Gambar 2. Bar Scale}

\section{Analisis Verifikatif}

\section{Analisis Korelasi}

Dalam penelitian ini menggunakan analisis korelasi produk moment (correlation product moment). Analisis korelasi produk moment adalah salah satu pendekatan untuk mengetahui keeratan antara satu variabel dengan variabel lainnya. Adapun rumus yang digunakan sebagai berikut : 


$$
r x y=\frac{n(\Sigma X Y)-(\Sigma X) \cdot(\Sigma Y)}{\sqrt{\left\{n \cdot \Sigma X^{2}-(\Sigma X)^{2}\right\}} \cdot \sqrt{\left\{n \cdot \Sigma Y^{2}-(\Sigma Y)^{2}\right\}}}
$$

Keterangan :

$$
\begin{array}{ll}
\text { rxy } & =\text { Korelasi xy } \\
\mathrm{n} & =\text { Jumlah sampel } \\
\mathrm{X} & =\text { Skor per item } \\
\mathrm{Y} & =\text { Total skor }
\end{array}
$$

Sumber: Riduwan (2013:136)

Adapun rancangan analisis untuk penelitian ini dapat dilihat pada gambar beikut ini :
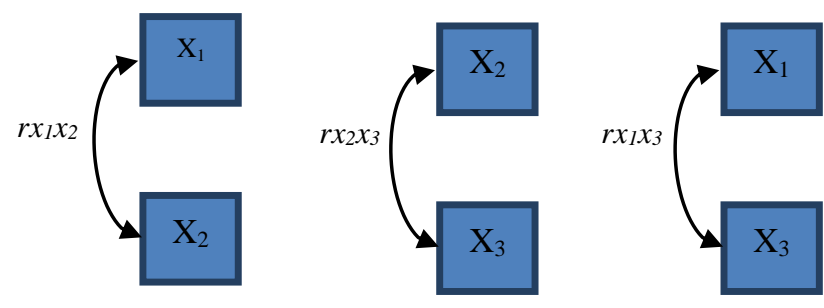

Gambar 3. Korelasi $X_{1}$ terhadap $X_{2}, X_{2}$ terhadap $X_{3}, X_{1}$ terhadap $X_{3}$ Sumber : Hasil analisi, 2017
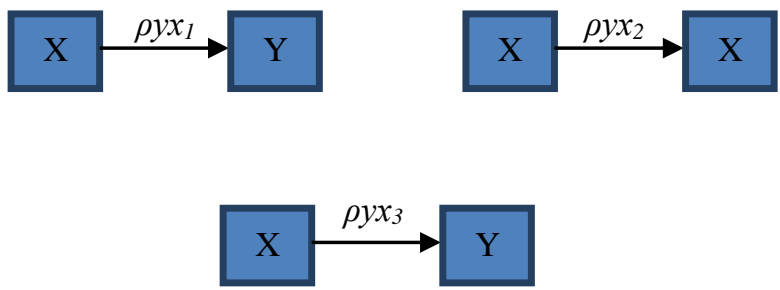

Gambar 4. Pengaruh $X_{1}$ terhadap $Y, X_{2}$ terhadap $Y, X_{3}$ terhadap $Y$ Sumber : Hasil analisi, 2017

\section{Path Analiysis}

Analisis jalur (path analysis) merupakan suatu metode penelitian yang utamanya digunakan untuk menguji kekuatan dari hubungan langsung dan tidak langsung seperangkat variabel bebas (eksogen) terhadap variabel terikat (endogen) (sandjojo, 2011:11). Model path analysis yang dibicarakan adalah pola hubungan sebab akibat.

Adapun rancangan analisis untuk penelitian ini dapat dilihat pada gambar 5 berikut ini:

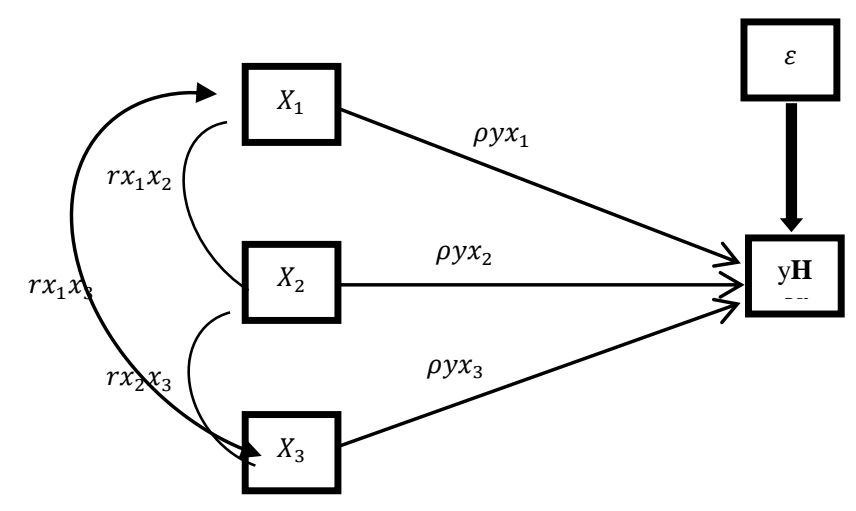

81. 


\section{Gambar 5.}

\section{Analisis Jalur}

Sumber : Hasill Analisis Penelitian, 2017

Persamaan analisis jalur, sebagai berikut:

$$
\mathrm{Y}=\rho y x_{1} \mathrm{X}_{1}+\rho y x_{2} \mathrm{X}_{2}+\rho y x_{3} \mathrm{X}_{3}+\rho y \varepsilon
$$

Dimana $: X_{1}=$ Harga

$X_{2}=$ Promosi

$X_{3}=$ Kualitas Pelayanan

$\mathrm{Y}=$ KeputusanPembelian

$\varepsilon=$ Variabel lain yang tidak diukur, tetapi mempengaruhi $\mathrm{Y}$

$\rho y x_{1}=$ Koefesien jalur yang menggambarkan besarnya pengaruh langsung $X_{1}$ terhadap $\mathrm{Y}$

$\rho y x_{2}=$ Koefesien jalur yang menggambar besarnya pengaruh langsung $X_{2}$ terhadap Y

$\rho y x_{3}=$ Koefesien jalur yang menggambar besarnya pengaruh langsung $X_{3}$ terhadap Y

$x_{1} x_{2} x_{3}=$ Korelasi $X_{1}, X_{2}$ dan $X_{3}$

\section{Koefesien Determinan}

Koefisien Determinan digunakan untukmenentukanbesarnya pengaruh dari variabel independen ke variabel dependent. Koefisien determinasi dilambangkan $\mathrm{r}^{2}$ merupakan proporsi hubungan antara $\mathrm{Y}$ dan $\mathrm{X}$. Nilai koefisien determinasi adalah diantara 0 (nol) dan 1 (satu).

Nilai $r^{2}$ yang mendekati 0 (nol) berarti kemampuan variabel-variabel independen dalam menjelaskan variabel dependen sangat kecil. Nilai $r^{2}$ mendekati 1 (satu) berarti variabel-variabel independen memberikan hampir semua informasi yang dibutuhkan untuk menjelaskan variabel dependen. Rumus untuk menghitung koefisien determinan

$$
\mathrm{KD}=r^{2} \times 100 \% \text {. }
$$

\section{Uji Hipotesis}

Uji hipotesis untuk mendeskripsikan ketiga variabel secara statistik adalah sebagai berikut:

Hipotesis $1:$ Terdapat korelasi harga dengan promosi

$\mathrm{H}_{0}: \mathrm{r}_{\mathrm{x} 1 \times 2}=0$ (tidak ada korelasi)

$\mathrm{H}_{1}: \mathrm{r}_{\mathrm{x} 1 \times 2} \neq 0$ (ada korelasi)

Hipotesis 2 : Terdapat korelasi promosi dengan kualitas pelayanan

$\mathrm{H}_{0}: \mathrm{r}_{\mathrm{x} 2 \times 3}=0$ (tidak ada korelasi)

$\mathrm{H}_{1}: \mathrm{r}_{\mathrm{x} 1 \times 2} \neq 0$ (ada korelasi)

Hipotesis 3 : Terdapat korelasi harga dengan kualitas pelayanan

$\mathrm{H}_{0}: \mathrm{r}_{\mathrm{x} 1 \times 3}=0$ (tidak ada korelasi)

$\mathrm{H}_{1}: \mathrm{r}_{\mathrm{x} 1 \times 3} \neq 0$ (ada korelasi)

Hipotesis 4 : Terdapat pengaruh harga terhadap keputusan Pembelian pada Kedai Makan Pa'Mur

$\mathrm{H}_{0}: \rho_{\mathrm{yx} 1}=0$ (tidak ada pengaruh) 


\section{$\mathrm{H}_{1}: \rho_{\mathrm{yx} 1} \neq 0$ (ada pengaruh)}

Hipotesis 5 : Terdapat pengaruh promosi terhadap keputusan pembelian pada Kedai Makan Pa'Mur

$\mathrm{H}_{0} \quad: \rho_{\mathrm{yx} 2}=0$ (tidak ada pengaruh)

$\mathrm{H}_{1} \quad: \rho_{\mathrm{yx} 2} \neq 0$ (ada pengaruh)

Hipotesis 6: Terdapat pengaruh kualitas pelayanan terhadap Keputusan pembelian pada Kedai Makan Pa'Mur

$\mathrm{H}_{0}: \rho_{\mathrm{yx} 3}=0$ (tidak ada pengaruh),

$\mathrm{H}_{1}: \rho_{\mathrm{yx} 3} \neq 0$ (ada pengaruh)

Hipotesis 7 : Terdapat pengaruh secara parsial harga, promosi dan kualitas pelayanan terhadap keputusan pembelian pada Kedai Makan Pa'Mur

$\mathrm{H}_{0}: \rho_{\mathrm{yx} 1}=\rho_{\mathrm{yx} 2}=\rho_{\mathrm{yx} 3}=0$ (tidak ada pengaruh)

$\mathrm{H}_{1}: \rho_{\mathrm{yx} 1}=\rho_{\mathrm{yx} 2}=\rho_{\mathrm{yx} 3} \neq 0$ (ada pengaruh)

Hipotesis 8 : Terdapat pengaruh secara simultan harga, promosi dan kualitas pelayanan terhadap keputusan pembelian pada Kedai Makan Pa'Mur $\mathrm{H}_{0}: \rho_{\mathrm{yx} 1}=\rho_{\mathrm{yx} 2}=\rho_{\mathrm{yx} 3}=0$ (tidak ada pengaruh)

$\mathrm{H}_{1}: \rho_{\mathrm{yx} 1}=\rho_{\mathrm{yx} 2}=\rho_{\mathrm{yx} 3} \neq 0$ (ada pengaruh)

\section{HASIL DAN PEMBAHASAN}

\section{HASIL PENELITIAN}

Profil Responden

\section{- Jenis Kelamin}

Tabel 3. Profil Jenis Kelamin Pelanggan Kedai Pa'Mur

\begin{tabular}{|c|l|r|r|}
\hline NO & \multicolumn{1}{|c|}{$\begin{array}{c}\text { JENIS } \\
\text { KELAMIN }\end{array}$} & $\begin{array}{c}\text { JUMLAH } \\
(\text { Org })\end{array}$ & $\begin{array}{c}\text { PERSENTASE } \\
(\boldsymbol{\%})\end{array}$ \\
\hline 1 & Pria & 214 & 59 \\
\hline 2 & Wanita & 151 & 41 \\
\hline \multicolumn{2}{|c|}{ JUMLAH } & $\mathbf{3 6 5}$ & $\mathbf{1 0 0 . 0 0}$ \\
\hline \multicolumn{2}{|c|}{ Sumber: Hasil Olah Data Jawaban Responden, 2017 }
\end{tabular}

Berdasarkan Tabel 3 diketahui bahwa dari 365 responden terdapat 214 responden atau 59\% adalah pria dan sisanya 151 responden atau $41 \%$ adalah perempuan. Berdasarkan data tersebut menunjukkan bahwa mayoritas responden adalah pria dengan jumlah 214 orang.

\section{- pekerjaan}

Tabel 4. Profil Pekerjaan Pelanggan Kedai Pa'Mur

\begin{tabular}{|c|l|r|r|}
\hline NO & \multicolumn{1}{|c|}{$\begin{array}{c}\text { TINGKAT } \\
\text { PENDIDIKAN }\end{array}$} & $\begin{array}{c}\text { JUMLAH } \\
(\text { Org })\end{array}$ & $\begin{array}{c}\text { PERSENTASE } \\
(\%)\end{array}$ \\
\hline 1 & Pelajar & 21 & 6 \\
\hline 2 & Wirausaha & 77 & 21 \\
\hline 3 & Pegawai Swasta & 173 & 47 \\
\hline
\end{tabular}




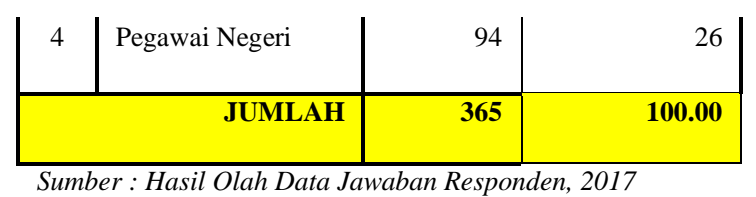

Berdasarkan data diketahui bahwa dari 365 responden pelanggan Kedai Makan Pa'Mur terdapat 21 responden atau 6\% pelajar, 77 responden atau $21 \%$ memiliki pekerjaan sebagai wirausaha dan 173 responden atau $47 \%$ memiliki pekerjaan sebagai pegawai swasta serta 94 responden atau $26 \%$ memiliki pekerjaan sebagai pegawai negri. Berdasarkan data diatas maka mayoritas pelanggan Kedai Makan Pa'Mur memiliki pekerjaan sebagai pegawai swasta dengan jumlah $47 \%$ dari total pelanggan.

\section{- Kunjungan}

Tabel 5. Profil kunjungan Pelangga Kedai Pa'Mur

\begin{tabular}{|c|c|c|c|}
\hline NO & KUNJUNGAN & $\begin{array}{l}\text { JUMLAH } \\
\text { (Org) }\end{array}$ & $\begin{array}{c}\text { PERSENTASE } \\
(\%)\end{array}$ \\
\hline 1 & Sekali & 144 & 39 \\
\hline 2 & $\geq$ Sekali & 221 & 61 \\
\hline & JUMLAH & 365 & 100.00 \\
\hline
\end{tabular}

Berdasarkan data di atas diketahui bahwa dari 365 responden yang makan di Kedai Makan Pa'Mur terdapat 144 responden atau $39 \%$ yang baru berkunjung untuk makan di Kedai Makan Pa'Mur, sementara 221 responden atau 61\% responden berkunjung untuk makan di Kedai Makan Pa'Mur sudah lebih dari satu kali. Jadi, dilihat dari segi kunjungan konsumen yang makan di Kedai Makan Pa'Mur adalah konsumen yang memang sudah menjadi langganan di Kedai Makan Pa'Mur.

\section{- Usia}

Tabel 6 Profil Usia Pelanggan Kedai Makan Pa'Mur

\begin{tabular}{|c|c|c|c|}
\hline NO & USIA (Thn) & $\begin{array}{c}\text { JUMLAH } \\
\text { (Org) }\end{array}$ & $\begin{array}{c}\text { PERSENTASE } \\
(\%)\end{array}$ \\
\hline 1 & $17-25$ & $\overline{146}$ & 40 \\
\hline 2 & $26-45$ & $\overline{219}$ & 60 \\
\hline & JUMLAH & 365 & $\overline{100.00}$ \\
\hline
\end{tabular}

Berdasarkan Tabel 6 dari 365 responden, terdapat 146 responden atau 40\% pelanggan Kedai Makan Pa'Mur berusia antara 17 - 25tahun dan 219responden atau 60\% pelanggan Kedai Makan Pa'Mur berusia antara 26 - 45 Tahun. Berdasarkan data tersebut menunjukkan bahwa mayoritas usia pelanggan Kedai Makan Pa’Mur antara 26 - 45 tahun dengan jumlah 219 orang.

\section{Hasil Pengujian Keabsahan Data}

84. 


\section{- Uji Validitas}

Tabel 7. Hasil Uji Validitas Variabel

\begin{tabular}{|c|l|c|}
\hline NO & \multicolumn{1}{|c|}{ VARIABEL } & KET. \\
\hline 1 & Harga & Valid \\
\hline 2 & Promosi & Valid \\
\hline 3 & Kualitas pelayanan & Valid \\
\hline 4 & Keputusan Pembelian & Valid \\
\hline
\end{tabular}

Sumber: Hasil Olah Data, 2017

\section{- Uji Reliabilitas}

Tabel 8. Hasil Uji Reliabilitas Variabel

\begin{tabular}{|c|l|c|c|l|}
\hline NO & \multicolumn{1}{|c|}{ VARIABEL } & $\begin{array}{c}\text { CRONBACH } \\
\text { ALPHA }\end{array}$ & $\begin{array}{c}\text { Nilai } \\
\boldsymbol{\alpha} \\
\text { Kritis }\end{array}$ & KET. \\
\hline 1 & Harga & 0.662 & 0,60 & Reliabel \\
\hline 2 & Promosi & 0.848 & 0,60 & Reliabel \\
\hline 3 & Kualitas pelayanan & 0.783 & 0,60 & Reliabel \\
\hline 4 & Keputusan Pembelian & 0.799 & 0,60 & Reliabel \\
\hline
\end{tabular}

\section{- Uji Normalitas Data}

Tabel 9. Uji Normalitas Data

\begin{tabular}{|c|c|c|c|c|}
\hline No. & Variabel & $\begin{array}{c}\text { Cronbach } \\
\text { Alpha }\end{array}$ & $\begin{array}{c}\text { Nilai } \\
\boldsymbol{\alpha}\end{array}$ & Keterangan \\
\hline 1 & Harga & 1.720 & 0,05 & $\begin{array}{c}\text { Distribusi } \\
\text { Normal }\end{array}$ \\
\hline 2 & Promosi & 2.142 & 0,05 & $\begin{array}{c}\text { Distribusi } \\
\text { Normal }\end{array}$ \\
\hline 3 & $\begin{array}{c}\text { Kualitas } \\
\text { pelayanan }\end{array}$ & 1.669 & 0,05 & $\begin{array}{c}\text { Distribusi } \\
\text { Normal }\end{array}$ \\
\hline 4 & $\begin{array}{c}\text { Keputusan } \\
\text { Pembelian }\end{array}$ & 1.683 & 0,05 & $\begin{array}{c}\text { Distribusi } \\
\text { Normal }\end{array}$ \\
\hline
\end{tabular}

Sumber : Data Hasil Pengolahan SPSS, 2017

\section{Analisis Deskriftif}

- Harga

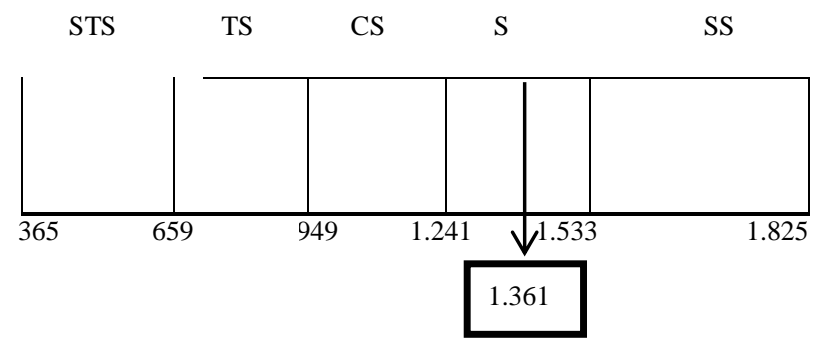

85 
Dapat dilihat bahwa variabel Harga $\left(\mathrm{X}_{1}\right)$ berada pada rentang nilai antara 1.241 sampai 1.533 maka harga pada Kedai Makan Pa'Mur secara umum berada pada kriteria jawaban responden setuju.Artinya

365 responden yang menjawab pernyataan tentang variabel harga tersebut menyatakan bahwa harga tidak menjadi sebuah halangan untuk melakukan atau menumbuhkan keputusan pembelian terhadap suatu produk.

- Promosi

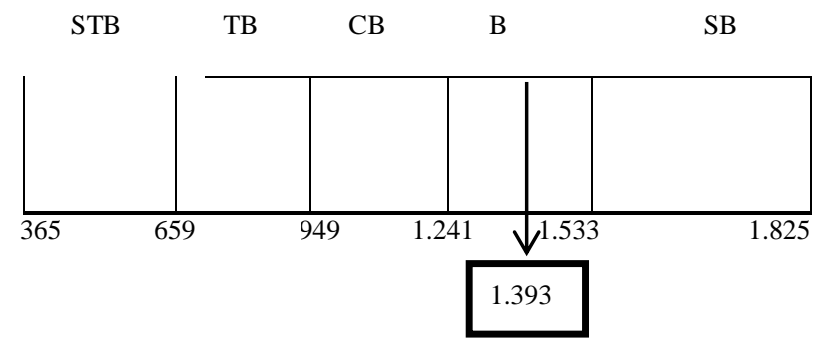

Dapat dilihat bahwa variabel promosi $\left(\mathrm{X}_{2}\right)$ berada pada rentang skala nilai antara 1.241 sampai 1.533dengan nilai skala rata-rata sebesar 1.393. Maka promosi yang dilakukan oleh Kedai Makan Pa'Mur secara umum berada pada kriteria Baik.

\section{- Kualitas Pelayanan}

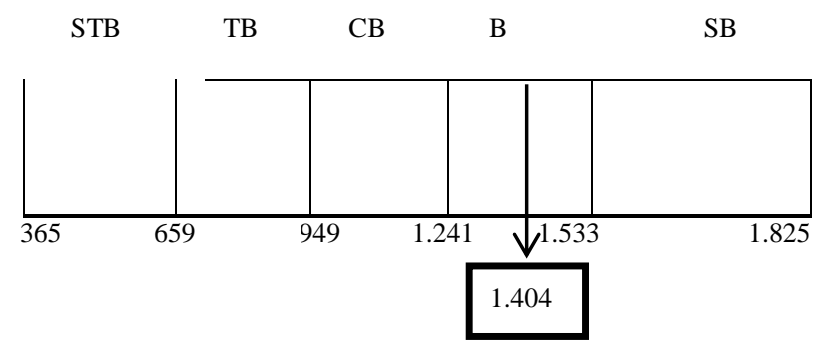

Dapat dilihat bahwa variabel kualitas pelayanan $\left(\mathrm{X}_{3}\right)$ berada pada rentang skala nilai antara 1.241 sampai 1.533dengan nilai skala rata-rata sebesar 1.404. Maka, menurut responden bahwa kualitas pelayanan yang dilakukan oleh Kedai Makan Pa'Mur secara umum berada pada kriteria Baik.

\section{- Keputusan Pembelian}

STS TS CS S SS

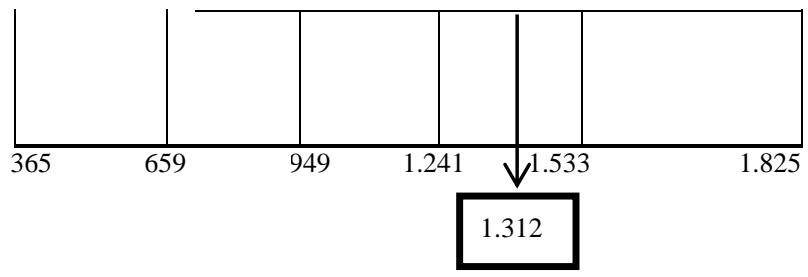

Total rata-rata jawaban 365 responden dari semua indikator variabel keputusan pembelian sebesar 1.312. Hal tersebut menandakan bahwa keputusan 
pembelian berada pada kriteria jawaban setuju karena berada pada rentang nilai interval $1.241-1.533$. Berarti bahwa apa yang telah dilakukan oleh Kedai Makan Pa'Mur dalam upaya untuk menarik keputusan pembelian konsumen sudah baik dilakukan.

\section{Analisis Verifikatif}

- Analisis Korelasi

\section{Besaran Korelasi Variabel Harga Dengan Promosi}

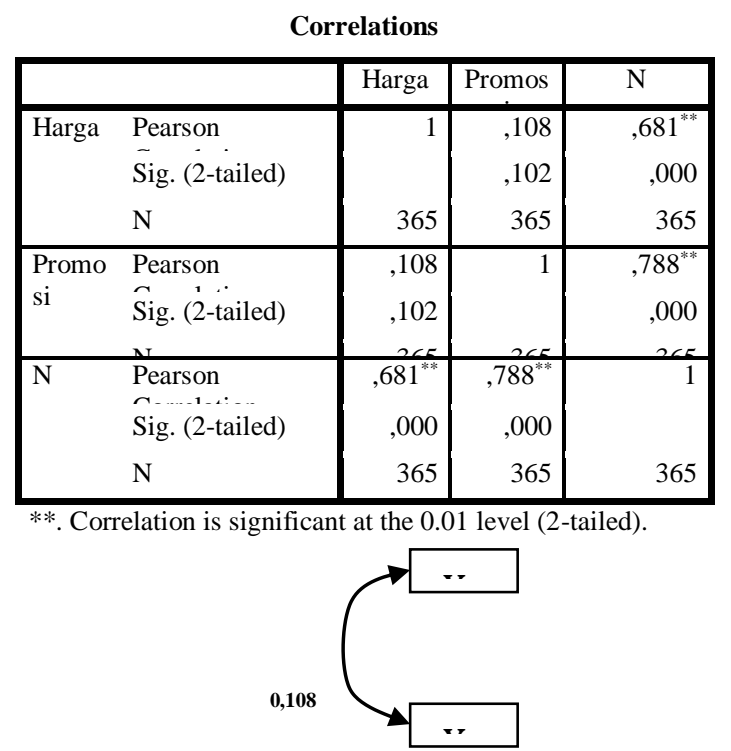

Dari hasil analisis diperoleh besaran koefisien korelasi diantara variabel bebas yaitu harga dengan promosi sebesar 0,108. Dengan demikian korelasi harga dengan promosi memiliki tingkat hubungan namun lemah dan nilainya positif dikarenakan tidak berada di interval koefisien nilai 0,60 sampai 0,799 yang berarti kuat (sugiyono, 2013:184).

\section{Besaran Korelasi Promosi Dengan Kualitas Pelayanan}

\section{Correlations}

\begin{tabular}{|ll|r|r|r|}
\hline & & Harga & Promosi & \multicolumn{1}{c|}{ N } \\
\hline Harga & Pearson Correlation & 1 &, $653^{* *}$ &, $912^{* *}$ \\
& Sig. (2-tailed) & &, 000 &, 000 \\
& $\mathrm{~N}$ & 365 & 365 & 365 \\
\hline Promosi & Pearson Correlation &, $653^{* *}$ & 1 &, $907^{* *}$ \\
& Sig. (2-tailed) &, 000 & &, 000 \\
& $\mathrm{~N}$ & 365 & 365 & 365 \\
\hline $\mathrm{N}$ & Pearson Correlation &, $912^{* *}$ &, $907^{* *}$ & 1 \\
& Sig. (2-tailed) &, 000 &, 000 & \\
& $\mathrm{~N}$ & 365 & 365 & 365 \\
\hline
\end{tabular}

**. Correlation is significant at the 0.01 level (2-tailed). 


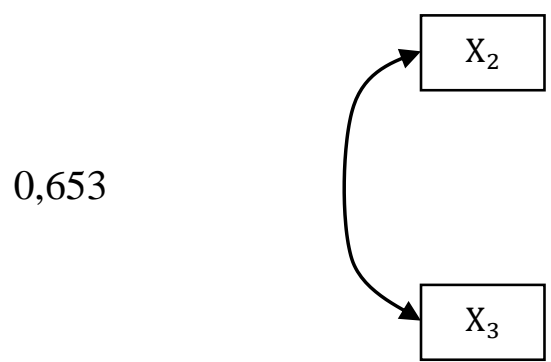

Dari hasil analisis diperoleh besaran koefisien korelasi diantara variabel bebas yaitu promosi dengan kualitas pelayanan sebesar 0,653. Dengan demikian promosi dengan kualitas pelayanan memiliki tingkat korelasi yang kuat dan searah nilainya positif dikarenakan berada di interval koefisien nilai 0,60 sampai 0,799 (sugiyono, 2013:184).

\section{Besaran Korelasi Harga dengan Kualitas Pelayanan}

\begin{tabular}{|ll|r|r|r|}
\hline \multicolumn{1}{|c|}{ Correlations } \\
\hline Harga & Pearson Correlation & \multicolumn{1}{c|}{ Harga } & K_Pelayanan & \multicolumn{1}{c|}{ N } \\
& Sig. (2-tailed) & 1 &, $353^{* *}$ &, $793^{* *}$ \\
& $\mathrm{~N}$ & &, 000 &, 000 \\
& & 365 & 365 & 365 \\
\hline K_Pelayan & Pearson Correlation &, $353^{* *}$ & 1 &, $850^{* * *}$ \\
an & Sig. (2-tailed) &, 000 & &, 000 \\
& N & 365 & 365 & 365 \\
\hline N & Pearson Correlation &, $793^{* *}$ &, $850^{* * *}$ & 1 \\
& Sig. (2-tailed) &, 000 &, 000 & \\
& N & 365 & 365 & 365 \\
\hline
\end{tabular}

**. Correlation is significant at the 0.01 level (2-tailed).

0,353

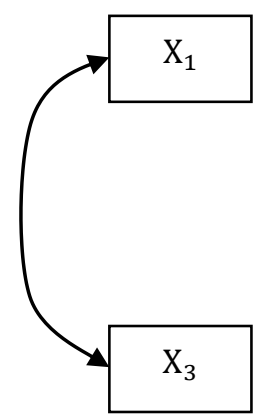

Dari hasil analisis diperoleh besaran koefisien korelasi diantara variabel bebas yaitu harga dengan kualitas pelayanan sebesar 0,353. Dengan demikian harga dengan kualitas pelayanan memiliki tingkat korelasi yang rendah dan searah nilainya positif dikarenakan berada di interval koefisien nilai 0,20 sampai 0,399 (sugiyono, 2013:184).

\section{- Analisis Jalur}

\section{Koefesien Jalur Antar Variabel}




\section{a. Koefesien Jalur Variabel X Terhadap Y}

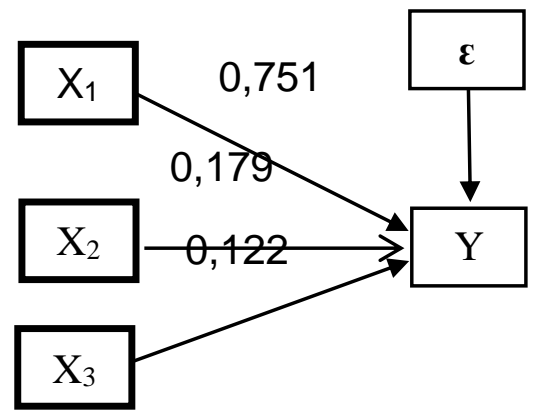

Berdasarkan Gambar di atas terlihat bahwa besaran derajat asosiatif atau koefisien jalur variabel harga $(0,751)$ lebih tinggi dibandingkan kedua variabel lain yaitu promosi $(0,179)$ dan kualitas pelayanan $(0,122)$, artinya harga lebih berpengaruh terhadap keputusan pembelian. Dengan bentuk persamaan sebagai berikut :

$Y=\left(0,751 X_{1}\right)+0,179 X_{2}+\left(0,122 X_{3}\right)+\varepsilon$

2. Besaran Pengaruh Parsial Variabel

a. Pengaruh Parsial Variabel $\mathrm{X}_{1}$ Terhadap $\mathrm{Y}$

\begin{tabular}{|c|l|c|c|}
\hline Variabel & \multicolumn{1}{|c|}{$\begin{array}{c}\text { Interpretasi } \\
\text { Analisis Jalur }\end{array}$} & Perhitungan & $\begin{array}{c}\text { Besarnya } \\
\text { Pengaruh }\end{array}$ \\
\hline \multirow{2}{*}{$\mathrm{X}_{1}$} & $\begin{array}{l}\text { Pengaruh } \\
\text { langsung ke Y }\end{array}$ & $(0,751)^{2}$ & 0,5640 \\
\cline { 2 - 4 } & $\begin{array}{l}\text { Pengaruh tidak } \\
\text { langsung ke Y }\end{array}$ & $\begin{array}{l}0,751 \times(0,108) \\
\text { x 0,179 x 0,122 }\end{array}$ & 0,00177 \\
\hline \multicolumn{3}{|r}{ Jumlah } & $\mathbf{0 , 5 6 5 8}$ \\
\hline
\end{tabular}

Sumber : Hasil Pengolahan Data 2017

Berdasarkan Tabel 4.32 terlihat bahwa pengaruh variabel harga terhadap keputusan pembelian adalah 0,5658 atau $56,58 \%$.

\section{b. Pengaruh Parsial Variabel $\mathrm{X}_{2}$ Terhadap $\mathrm{Y}$}

\begin{tabular}{|c|l|c|c|}
\hline Variabel & \multicolumn{1}{|c|}{$\begin{array}{c}\text { Interpretasi } \\
\text { Analisis Jalur }\end{array}$} & Perhitungan & $\begin{array}{c}\text { Besarnya } \\
\text { Pengaruh }\end{array}$ \\
\hline \multirow{2}{*}{$\mathrm{X}_{2}$} & $\begin{array}{l}\text { Pengaruh } \\
\text { langsung ke Y }\end{array}$ & $0,179^{2}$ & 0,03204 \\
\cline { 2 - 4 } & $\begin{array}{l}\text { Pengaruh tidak } \\
\text { langsung ke Y }\end{array}$ & $\begin{array}{c}0,751 \times 0,179 \times \\
0,653 \times 0,122\end{array}$ & 0,01071 \\
\hline \multicolumn{3}{|r}{} \\
\hline
\end{tabular}

89. 
Sumber : Hasil Pengolahan Data 2017

Berdasarkan Tabel di atas terlihat bahwa pengaruh variabel promosi terhadap keputusan pembelian adalah 0,04275 atau $4,28 \%$.

\section{c. Pengaruh Parsial Variabel $\mathrm{X}_{3}$ Terhadap $\mathrm{Y}$}

\begin{tabular}{|c|l|c|c|c|}
\hline Variabel & $\begin{array}{c}\text { Interpretasi } \\
\text { Analisis Jalur }\end{array}$ & Perhitungan & $\begin{array}{c}\text { Besarnya } \\
\text { Pengaruh }\end{array}$ \\
\hline \multirow{2}{*}{$\mathrm{X}_{3}$} & $\begin{array}{l}\text { Pengaruh } \\
\text { langsung ke } \mathrm{Y}\end{array}$ & $0,122^{2}$ & 0,01488 \\
\cline { 2 - 5 } & $\begin{array}{l}\text { Pengaruh tidak } \\
\text { langsung ke } \mathrm{Y}\end{array}$ & $\begin{array}{c}0,751 \times 0,179 \times \mathrm{x} \\
0,122 \times 0,353\end{array}$ & 0,00579 \\
\hline \multicolumn{2}{|r}{ Jumlah } & $\mathbf{0 , 0 2 0 6 7}$ \\
\hline
\end{tabular}

Sumber : Hasil Pengolahan Data 2017

Berdasarkan Tabel di atas terlihat bahwa pengaruh variabel kualitas pelayanan terhadap keputusan pembelian adalah 0,02067 atau 2,07\%.

\section{a. Pengaruh Simultan Variabel X Terhadap Variabel Y}

\begin{tabular}{|c|c|c|c|c|c|c|}
\hline \multirow{2}{*}{ Var. } & \multirow{2}{*}{$\begin{array}{c}\text { Koefisien } \\
\text { Jalur }\end{array}$} & \multirow{2}{*}{$\begin{array}{l}\text { Pengaruh } \\
\text { Langsung }\end{array}$} & \multicolumn{3}{|c|}{ Pengaruh Tidak Langsung } & $\begin{array}{c}\text { Sub } \\
\text { Total } \\
\text { Pengar } \\
\text { uh }\end{array}$ \\
\cline { 4 - 7 } & & & $\mathbf{X}_{1}$ & $\mathbf{X}_{2}$ & $\mathbf{X}_{3}$ & \\
\hline $\mathrm{X}_{1}$ & 0,751 & 0,5640 & --- & --- & 0,00141 & 0,5658 \\
\hline $\mathrm{X}_{2}$ & 0,179 & 0,03204 & --- & 0,01071 & --- & 0,0428 \\
\hline $\mathrm{X}_{3}$ & 0,122 & 0,01488 & 0,00579 & --- & --- & 0,0207 \\
\hline & & & \multicolumn{5}{c}{ Total Pengaruh } & $\mathbf{0 , 6 2 9 2}$ \\
\hline
\end{tabular}

Sumber : Hasil Pengolahan Data 2017

Berdasarkan Tabel di atas menunjukan bahwa total pengaruh variabel harga, promosi dan kualitas pelayanan terhadap keputusan pembelian sebesar 0,6292 atau $62,92 \%$.

\section{Uji Hipotesis}

\section{a. Korelasi Antara Harga dan Promosi}

Harga $t_{\text {hitung }}$ di atas selanjutnya dibandingkan dengan $t_{\text {tabel }}$ pada tingkat kesalahan $5 \%, \mathrm{db}=\mathrm{n}-2=365-2=363$, maka diperoleh $\mathrm{t}_{\text {tabel }}=1,960$. Dengan demikian diketahui $t_{\text {hitung }}(2,0697)>t_{\text {tabel }}(1,960)$, maka dapat dinyatakan bahwa $\mathrm{H}_{\mathrm{o}}$ ditolak, artinya ada hubungan yang signifikan antara Harga dengan Promosi.

\section{b. Korelasi Antara Promosi dan Kualitas Pelayanan}

Harga $t_{\text {hitung }}$ di atas selanjutnya dibandingkan dengan $t_{\text {tabel }}$ pada tingkat kesalahan $5 \%, \mathrm{db}=\mathrm{n}-2=365-2=363$, maka diperoleh $\mathrm{t}_{\text {tabel }}=1,960$. Dengan demikian diketahui $t_{\text {hitung }}(16,427)<t_{\text {tabel }}(1,960)$, maka dapat dinyatakan bahwa $\mathrm{H}_{\mathrm{o}}$ ditolak, artinya ada hubungan yang signifikan antara promosi dan kualitas pelayanan. 


\section{c. Korelasi Antara Harga dan Kualitas Pelayanan}

Harga $t_{\text {hitung }}$ di atas selanjutnya dibandingkan dengan $t_{\text {tabel }}$ pada tingkat kesalahan 5\%, db $=\mathrm{n}-2=365-2=363$, maka diperoleh $\mathrm{t}_{\text {tabel }}=1,960$. Dengan demikian diketahui $t_{\text {hitung }}(7,188)>t_{\text {tabel }}(1,960)$, maka dapat dinyatakan bahwa $\mathrm{H}_{\mathrm{o}}$ ditolak, artinya ada hubungan yang signifikan antara harga dan kualitas pelayanan.

\section{d. Pengaruh Harga Terhadap Keputusan Pembelian}

Dengan tingkat signifikan $(\alpha)=5 \%$, degree of freedom $(\mathrm{df})=(\mathrm{n}-2)=365-2$ $=363$ diperoleh $\mathrm{t}_{\text {tabel }}=1,960$. Berdasarkan hasil perhitungan, menunjukan bahwa thitung $=19,301$ dan sig. 0,000. menunjukan bahwa nilai sig. $(0,000)<\alpha$ $(0,05)$ dan $t_{\text {hitung }}(4,464)>t_{\text {tabel }}(1,960)$ maka $H_{0}$ tolak. Dengan demikian dapat disimpulkan bahwa harga secara parsial berpengaruh terhadap keputusan pembelian dikarenakan harga menjadi pembanding terhadap kebutuhan dasar konsumen dan atau menjadi dasar dalam melakukan pembelian dibandingkan dengan prodak yang dijualnya.

\section{e. Pengaruh Promosi Terhadap Keputusan Pembelian}

Dengan tingkat signifikan $(\alpha)=5 \%$, degree of freedom $(\mathrm{df})=(\mathrm{n}-2)=365-2$ $=363$ diperoleh $t_{\text {tabel }}=1,960$. Berdasarkan hasil perhitungan, menunjukan bahwa $t_{\text {hitung }}=3,715$ dan sig. 0,000 . Menunjukan bahwa nilai sig. $(0,000)<\alpha$ $(0,05)$ dan $t_{\text {hitung }}(3,715)>t_{\text {tabel }}(1,960)$ maka $H_{0}$ tolak. Dengan demikian dapat disimpulkan bahwa promosi secara parsial berpengaruh terhadap keputusan pembelian dikarenakan promosi merupakan alat informasi bagi calon konsumen untuk melakukan pembelian.

\section{f. Pengaruh Kualitas Pelayanan Terhadap Keputusan Pembelian}

Dengan tingkat signifikan $(\alpha)=5 \%$, degree of freedom $(\mathrm{df})=(\mathrm{n}-2)=365-2$ $=363$ diperoleh $t_{\text {tabel }}=1,960$. Berdasarkan hasil perhitungan, menunjukan bahwa $\mathrm{t}_{\text {hitung }}=2,376$ dan sig. 0,018 . menunjukan bahwa nilai sig. $(0,018)<\alpha(0,05)$ dan $t_{\text {hitung }}(2,376)>t_{\text {tabel }}(1,960)$ maka $\mathrm{H}_{\mathrm{o}}$ tolak. Dengan demikian dapat disimpulkan bahwa kualitas pelayanan secara parsial berpengaruh terhadap keputusan pembelian dikarenakan kualitas pelayanan mempunyai daya tarik tertentudan merupakan bagian terpenting bagi pembeli dalam melakukan pembelian.

\section{g. Pengaruh Variabel Secara Simultan Variabel X Terhadap Y}

Dengan tingkat signifikan $(\alpha)=5 \%$, degree of freedom $(\mathrm{df})=(\mathrm{n}-4)=365-4$ $=361$, diperoleh $\mathrm{f}_{\text {tabel }}=2,41$. menunjukan bahwa $\mathrm{f}_{\text {hitung }}=141,984$ dan sig. 0,000. Bahwa nilai sig. $(0,000)<\alpha(0,05)$ dan $f_{\text {hitung }}(141,984)>f_{\text {tabel }}(2,41)$ maka $\mathrm{H}_{\mathrm{o}}$ ditolak. Sehingga dapat disimpulkan bahwa harga, promosi dan kualitas pelayanan berpengaruh simultan terhadap keputusan pembelian karena harga, promosi dan kualitas pelayanan merupakan bagian yang sangat tak terpisahkan dalam keputusan pembelian suatu barang/produk.

\section{PEMBAHASAN}

\section{Variabel Harga}

Variabel harga pada Kedai Makan Pa'Mur memiliki10 indikator dimana 365 responden seluruhnya menyatakan jawaban terhadap kuesioner yang diberikan. Kesepuluh indikator tersebut berada pada rentang skala nilai 1.241 sampai1.533 
dengan kriteria setuju, artinya harga di Kedai Makan Pa'Mur dinilai baik oleh konsumen.

\section{Variabel Promosi}

Variabel promosi pada Kedai Makan Pa'Mur memiliki 9 indikator dimana 365 responden seluruhnya menyatakan jawaban terhadap kuesioner yang diberikan. Ke sembilan indikator tersebut berada pada rentang skala nilai 1.241sampai1.533 dengan kriteria baik, artinya bahwa promosi yang dilakukan oleh Kedai Makan Pa'Mur tersampaikan baik kepada responden.Sebab promosi dalam dunia usaha sangat penting peranannya untuk dapat menyampaikan prodak atau usaha bisnis kepada calon pembeli dan hal ini cukup baik dilakukan oleh Kedai Makan Pa'Mur.

\section{Variabel Kualitas Pelayanan}

Variabel kualitas pelayanan pada Kedai Makan Pa'Mur memiliki 11 indikator dimana 365 responden seluruhnya menyatakan jawaban terhadap kuesioner yang diberikan. Namun terdapat satu indikator yang tidak dijawab oleh responden seutuhnya, yaituindikator pelayan melakukan dengan cepat ketika memenuhi pesanan konsumen, artinya bahwa indikator tersebut konsumen beranggapan bahwa hanya dengan menjawab ke empat pilihan tersebut sudah dirasa cukup karena pada dasarnya konsumen memahami akan kondisi pelayan di Kedai Makan Pa'Mur tersebut.Dan 11 indikator tersebut berada pada rentang skala nilai 1.241sampai 1.533 dengan kriteria baik, artinya kualitas pelayanan di Kedai Makan Pa'Mur dapat diterima dengan baik oleh responden.

\section{Variabel Keputusan Pembelian}

Keputusan pembelian pada Kedai Makan Pa'Mur memiliki 9 indikator, dimana 365 responden seluruhnya menyatakan jawaban terhadap kuesioner yang diberikan. Dan hanya dua indikator yang dijawab oleh responden tidak secara utuh yaitu indikator kecenderungan untuk membeli karena harga yang ditawakan murah, artinya bahwa responden beranggapan untuk indikator ini diperlukan menjawab secara utuh, terlepas apapun jawabannya dari responden informasi yang diberikan oleh konsumen satu ke konsumen lain merupakan bentuk informasi penyampaian produk yang ditawarkan. Dan dari sembilan indikator tersebut berada pada rentang skala nilai1.241sampai1.533 dengan kriteria setuju, artinya keputusan pembelianterhadap menu makanan di Kedai Makan Pa'Murdinilai baik oleh konsumen.

\section{Korelasi Antar Variabel}

- Korelasi harga $\left(\mathrm{X}_{1}\right)$ dengan promosi $\left(\mathrm{X}_{2}\right)$, mempunyai nilai koefesien korelasi (r) sebesar 0,086 dan jika diinterpretasikan dengan keeratan hubungan kedua variabel ini mempunyai tingkat hubungan yang rendah(sugiyono, 2013:184). Dan searah karena nilainya positif. Meski memiliki hubungan rendah terhadap promosi, harga merupakan satu-satunya unsur bauran pemasaran yang memberikan pemasukan atau pendapatan bagi perusahaan, sedangkan ketiga unsur lainnya (produk, distribusi, dan promosi) menyebabkan timbulnya biaya (pengeluaran).

- Korelasi promosi $\left(\mathrm{X}_{2}\right)$ dengan kualitas pelayanan $\left(\mathrm{X}_{3}\right)$, mempunyai nilai koefisien korelasi sebesar 0,653. Dengan demikian promosi dengan kualitas pelayanan memiliki tingkat korelasi yang kuat dan searah nilainya positif 
dikarenakan berada di interval koefisien nilai 0,60 sampai 0,799 (sugiyono, 2013:184). Ini menunjukan bahwa jika promosi yang sering dilakukan, maka kualitas pelayananan pun akan ditingkatkan. Karena jika sebuah produk atau tempat makan dipromosikan maka konsekuensi yang harus diterima bahwa apa yang dipromosikan itu harus benar-benar ada dan dilakukan termasuk kualitas pelayanan.

- Korelasi harga $\left(X_{1}\right)$ dengan kualitas pelayanan $\left(X_{3}\right)$, mempunyai nilai koefisien korelasi sebesar 0,353. Dengan demikian harga dengan kualitas pelayanan memiliki tingkat korelasi yang rendah dan searah nilainya positif dikarenakan berada di interval koefisien nilai 0,20 sampai 0,399 (sugiyono, 2013:184). Hal ini menunjukan bahwa jika harga ditingkatkan, maka kualitas pelayananpun akan ditingkatkan, karena penetapan harga memiliki beberapa tujuan yang salah satunya adalah berorientasi peda citra produsen atau produk yang dijual artinya bahwa jika kualitas pelayanan yang diberikan oleh produsen, maka citra yang akan diterima oleh produsen dimata konsumen sudah barang tentu akan jelek.

\section{Pengaruh Parsial Harga $\left(\mathbf{X}_{1}\right)$ terhadap Keputusan Pembelian (Y)}

Pengaruh parsial antara variabel ini, memiliki nilai koefesien jalur sebesar 0,751. Dan dari hasil perhitungan pada tabel 4.32 diperoleh nilai besaran pengaruh harga terhadap keputusan pembelian sebesar 0,5658 atau 56,58\%. Menurut Schiffman dan Kanuk (2007, p173) bahwa konsumen dalam melakukan keputusan pembelian berdasarkan kepada keterjangkauan harga terhadap produk yang ditawarkan, harga sesuai dengan pendapatan calon konsumen. Sedangkan menurut Swastha dan Handoko (2008) Keputusan membeli konsumen mencakup beberapa komponen yaitu keputusan tentang jenis produk, keputusan tentang bentuk produk, keputusan tentang merek produk dan lainnya. Harga merupakan satu kesatuan yang penting dalam melakukan transaksi jual beli. Dengan nilai pengaruh tidak langsung terhadap keputusan pembelian sebesar 0,00141 atau 0,014\% menjadikan harga salah satu faktor dalam penentuan konsumen melakukan pembelian barang/produk karena jika dilihat nilai keseluruhan pengaruh harga terhadap keputusan pembelian yaitu sebesar 0,5654 atau 56.54\% artinya konsumen melakukan keputusan pembelian di kedai makan Pa'mur tetap melihat bandrol atau harga dari setiap menu yang ditawarkan/dijual.

\section{Pengaruh Parsial Promosi $\left(\mathbf{X}_{2}\right)$ Terhadap Keputusan Pembelian (Y)}

Kedua variabel ini, mempunyai nilai koefesien jalur sebesar 0,179. Dari hasil perhitungan pada tabel 4.33 diperoleh nilai besaran pengaruh promosi terhadap keputusan pembelian sebesar 0,0428 atau 4,28\%. Artinya bahwa timbulnya keputusan pembelian konsumen disebabkan karena adanya promosi yang dilakukan oleh pihak Kedai Makan Pa'Mur secara variatif dan menarik. Karena konsumen aktual adalah konsumen yang langsung membeli produk yang ditawarkan pada saat atau sesaat setelah promosi produk tersebut dilancarkan perusahaan

\section{Pengaruh Parsial Kualitas Pelayanan $\left(\mathbf{X}_{3}\right)$ Terhadap Keputusan Pembelian (Y)}

Kedua variabel ini memiliki koefesien jalur sebesar 0,0207. Dari hasil perhitungan pada tabel 4.34 diperoleh nilai besaran pengaruh kualitas pelayanan terhadap keputusan pembelian sebesar 0,0207 atau 2,07\%. Artinya bahwa 
keputusan konsumen/pembeli dalam memutuskan pembelian di Kedai makan Pa'Mur dipengaruhi oleh kualitas pelayanan hanya 4,27\% sisanya dipengaruhi oleh faktor lain.

\section{Pengaruh Simultan Antara Variabel X Terhadap Y}

Nilai koefesien determinasi pengaruh harga, promosi dan kualitas pelayanan terhadap keputusan pembelian sebesar 0,6292. Sehingga dapat diartikan bahwa total pengaruh harga $\left(\mathrm{X}_{1}\right)$, promosi $\left(\mathrm{X}_{2}\right)$ dan kualitas pelayanan $\left(\mathrm{X}_{3}\right)$ terhadap keputusan pembelian (Y) sebesar 0,6292 atau sebesar 62,92\%. Berdasarkan hasil penelitian ini menunjukan bahwa harga, promosi dan kualitas pelayanan memiliki kontribusi terhadap keputusan pembelian (Y) sebesar 62,92\% sedangkan sisanya 0,3708 atau 37,08\% merupakan pengaruh kontribusi lain ( $(\varepsilon)$ yang tidak diteliti.

\section{SIMPULAN DAN SARAN}

\section{SIMPULAN}

Dari penelitian ini dihasilkan beberapa temuan dari pembahasan bab sebelumnya. Berikut hasil temuannya yaitu :

1. Harga yang ditawarkan oleh Kedai Makan Pa'Mur kepada konsumen sudah baik, ini dibuktikan dengan hasil penelitian bahwa konsumen menyatakan setuju dengan harga tersebut. Karena konsumen beranggapan bahwa harga bukan merupakan sebuah halangan untuk melakukan keputusan dalam pembelian terhadap produk yang ditawarkan. Ini dibuktikan dengan nilai skor dari hasil jawaban responden terhadap kuesioner yang disebar dengan nilai rata-rata sebesar 1.323 dengan kriteria jawaban responden setuju. Dan terdapat indikator yang memiliki nilai terendah yaitu indikator kesesuaian harga dengan kenyaman tempat dimana nilai skornya adalah 1.323.

2. Promosi yang dilakukan oleh Kedai Makan Pa'Mur sudah baik, hal ini dibuktikan dengan nila skor rata-rata hasil jawaban responden sebesar 1.393 yang berada pada nilai interval 1.241 sampai 1.533 dengan kriteria jawaban responden baik. Akan tetapi pelaksanaan promosi yang dilakukan oleh Kedai Makan Pa'mur lewat media sosial belum maksimal, itu terlihat dari besaran skor nilai yang didapat sebesar 1.351 dan merupakan nilai skor terendah.

3. Kualitas pelayanan di Kedai Makan Pa'Mur dapat diterima dengan baik oleh responden. Itu dibuktikan dengan nilai skor rata-ratanya sebesar 1.404 dan berada pada rentang skala nilai 1.241 sampai 1.533 dengan kriteria jawaban baik.Namun masih ada yang dirasakan kurang oleh konsumen yaitu perhatian yang diberikan oleh pelayan terhadap konsumen dalam melakukan pelayanan. Hal itu dibuktikan dengan nilai skor sangat rendah yaitu 1.347.

4. Keputusan pembelian terhadap menu makanan di Kedai Makan Pa'Mur dinilai baik oleh konsumen, hal tersebut dibuktikan dengan nilai skor rata-rata sebesar 1.312 yang berada pada rentang nilai 1.241 sampai 1.533 dengan kriteria jawaban responden setuju. Artinya bahwa apa yang telah dilakukan oleh Kedai Makan Pa'Mur dalam upaya untuk menarik keputusan pembelian konsumen sudah baik dilakukan. Namun ada hal yang masih kurang dalam upaya memenuhi keputusan pembelian dimana calon pembeli membutuhkan informasi secara online lewat media sosial. Hal ini belum atau masih kurang dilakukakn oleh Kedai Makan Pa'Mur terlihat dari nilai indikatornya memilki nilai sangat rendah yaitu sebesar 858 . 
5. Besaran nilai harga dengan promosi yaitu 0,108. dan jika diinterpretasikan dengan keeratan hubungan kedua variabel ini mempunyai tingkat hubungan yang rendah (sugiyono, 2013:184) dan searah karena nilainya positif. Meskipun rendah terjadinya hubungan kedua variabel tersebut, tapi hal ini menunjukan bahwa harga berperan sebagai sarana informasi terhadap calon konsumen, informasi tersebut bisa didapat dalam bentuk iklan atau bahkan promo-promo yang dilakukan oleh para penjual untuk menarik calon konsumen.

6. Besaran nilai promosi dengan kualitas pelayanan yaitu 0,653. Jika diinterpretasikan dengan keeratan hubungan kedua variabel ini mempunyai tingkat hubungan yang kuat (sugiyono, 2013:184) dan searah karena nilainya positif. Ini menunjukan bahwa jika promosi yang sering dilakukan, maka kualitas pelayananan pun akan ditingkatkan begitupun sebaliknya dengan meningkatkan kualitas pelayanan maka promosi yang dilakukanpun akan semakin meningkat karena dapat dijadikan sebagai nilai plus untuk menarik calon konsumen.

7. Besaran nilai harga dengan kualitas pelayanan yaitu 0,353. Jika diinterpretasikan dengan keeratan hubungan kedua variabel ini mempunyai tingkat hubungan yang rendah (sugiyono, 2013:184) dan searah karena nilainya positif. Hal ini menunjukan bahwa jika harga ditingkatkan, maka kualitas pelayananpun akan ditingkatkan, karena penetapan harga memiliki beberapa tujuan yang salah satunya adalah berorientasi peda citra produsen atau produk yang dijual artinya bahwa jika kualitas pelayanan yang diberikan oleh produsen, maka citra yang akan diterima oleh produsen dimata konsumen sudah barang tentu akan jelek. Sebaliknya jika kualitas pelayanan lebih ditingkatkan, maka akan berdampak pada meningkatnya harga sebuah produk atau barang, karena Pada prinsipnya, konsistensi dan superioritas kualitas pelayanan berpotensi menciptakan kepuasan pelanggan yang pada gilirannya akan memberikan sejumlah manfaat seperti laba yang diperoleh bisa meningkat.

8. Besaran pengaruh harga terhadap keputusan pembelian mempunyai nilai sebesar 0,5658. Promosi terhadap keputusan pembelian mempunyai nilai sebesar 0,0428. Kualitas pelayanan terhadap keputusan pembelian mempunyai nilai sebesar 0,0207. Dari hasil yang diperoleh tersebut menunjukan bahwa harga lebih besar dan dominan memberikan kontribusi terhadap keputusan pembelian dibandingkan promosi dan kualalitas pelayanan $(0,5628>0,0428>$ 0,0207).

Harga, promosi dan kualitas pelayanan berpengaruh secara signifikan terhadap keputusan pembelian (Y) sebesar 62,92\%. Sisanya yaitu sebesar 37,08\% merupakan pengaruh kontribusi lain $(\varepsilon)$ yang tidak diteliti seperta kualitas prodak, lokasi, kepuasan pelanggan dan lain sebagainya. Dan berdasarkan hasil hipotesis yang diperoleh dapat disimpulkan bahwa harga, promosi dan kualitas pelayanan berkontribusi secara simultan dan signifikan terhadap keputusan pembelian dapat diterima.

\section{SARAN}

Berdasarkan hasil pembahasan dan kesimpulan penelitian ini, maka disarankan hal-hal sebagai berikut :

95. 
1. Sebaiknya Kedai Makan Pa'Mur lebih memperhatikan lagi kondisi atau tempat makan agar bisa nyaman ketika konsumen melakukan pembelian, sebab dengan kondisi sekarang konsumen berpendapat bahwa harga yang ditawarkan sudah sesuai dengan kenyaman tempat yang ada. Artinya bahwa konsumen menganggap wajar dengan harga seperti itu. Sementara menu yang ditawarkan merupakan menu yang berbeda dan seharusnya menjadi fokus perbaikan oleh Kedai makan Pa'Mur agar bisa menaikan omzetnya. Satu sisi yang lain hendaknya Kedai makan Pa'Mur tetap mempertahankan kesesuaian harga dengan rasa yang enak, karena konsumen berpendapat bahwa untuk makan enak ternyata tidak mahal.

2. Sebaiknya kedai Makan Pa'Mur lebih aktif lagi melakukan promosi lewat media sosial seperti Facebook, Instagram, line Shop dan lainnya, karena dari segi biaya yang dikeluarkan bentuk promosi ini sangatlah murah serta akan lebih banyak jangkauan calon konsumen untuk melakukan keputusan pembelian kepada Kedai makan Pa'Mur. Dan hal tersebut dinyatakan oleh konsumen bahwa informasi produk Kedai Makan Pa'Mur hendaknya disampaikan juga lewat media sosial.Sementara bentuk promosi atau penjualan saat ini yang sudah dilakukan salah satunya penjualan dengan cara menjual secara dor to dor tetap dipertahankan oleh produsen.

3. Sebaiknya produsen atau pemilik Kedai Makan Pa'Mur memberikan bimbingan lagi kepada karyawannya tentang bagaimana cara melakukan pelayanan yang baik dan benar kepada konsumen karena konsumen masih beranggapan bahwa kualitas pelayanan yang diberikan oleh pelayan kepada konsumen masih kurang artinya responsip pelayanan ketika konsumen membeli kurang cepat direspon. Dan pelayan agar tetap mempertahankan sikap pelayan sangat memahami pelanggan yang sering makan di Kedai makan Pa'Mur. Karena dengan mempertahankan sikap seperti itu merupakan nilai plus bagi konsumen.

4. Sebaiknya pemilik atau Kedai Makan Pa'Mur melakukan terobosan dengan cara menjual produk secara online, karena belum adanya informasi mengenai produk yang ditawarkan melalui media sosial menjadi bahan atau informasi calon konsumen untuk melakukan keputusan pembelian. Dan tetap mempertahankan harga yang ditawarkan saat ini, karena konsumen beranggapan bahwa harga yang ditawarkan sangat murah.

Adanya kajian atau penelitian lebih lanjut tentang variabel lainnya yang mempengaruhi variabel keputusan pembelian pada Kedai Makan Pa'Mur Karawang yang tidak diteliti dalam penelitian ini sehingga diharapkan kekurangan atau kelemahan terhadap Kedai Makan Pa'Mur bisa diketahui secara menyeluruh.

\section{DAFTAR PUSTAKA}

Anwar Prabu Mangkunegara. 2005. PerilakuKonsumen. Bandung: Refika Aditama.

Arikunto, Suharsimi. 2006. rosedur Penelitian Suatu Pendekatan Praktik. Jakarta :Renikacipta.

Basu Swastha dan Irawan. 2001. Manajemen Pemasaran Modern. Yogyakarta: Liberty. 
BasuSwasthadan T. Hani Handoko. 2000. Manajemen Pemasaran (Analisa Perilaku Konsumen). Yogyakarta : BPFE UGM.

Cravens, David W. 1998. Pemasaran Strategis.Jilid 2. Edisi Keempat. Cetakan Kedua. AhliBahasa Lina Salim. Jakarta: Erlangga.

Daryanto S.S. 1997. Kamus Bahasa Indonesia Lengkap. Surabaya: Apollo.

Engel, James, F, Roger D. Blackwell, dan Paul W. Miniard. 1994. Perilaku Konsumen. Edisi Keenam. Jilid 1. Jakarta: Penerbit Binarupa Aksara.

FandyTjiptonoet al.. 2008. Pemasaran Strategik. Yogyakarta: Andi Offset.

FandyTjiptono. 2007. Pemasaran Jasa. Malang: Bayumedia Publishing.

FandyTjiptono. 1997. Strategi Pemasaran Jasa. Yogyakarta: Andi Offset

Ferdinand, A.. 2002. Structural Equation Modeling dalam Penelitian Manajemen. Edisike 2. Semarang: BP UNDIP.

Freddy Rangkuti.2004.The Power of Brand. Jakarta: PT GramediaPustakaUtama.

Imam Ghozali. 2008. Model Persamaan Struktural Konsepdan Aplikasi dengan Program Amos 16.0. Semarang: Badan Penerbit UNDIP.

Imam Ghozali. 2005. Aplikasi Analisis Multivariate dengan program SPSS. Semarang. BadanPenerbit UNDIP.

Jonathan Sarwono. Tutty Martadiredja. 2008. Riset Bisnis Untuk Pengambilan Keputusan. Yogyakarta: Andi

Kotler, Philip \& Garry Armstrong. 2007. Marketing An Introduction (EightEdition). New Jersey: Pearson Prentice Hall.

Kotler, Philip \& Garry Armstrong. 2008. Prinsip-Prinsip Pemasaran. Edisi ke-12. Alihbahasa: BobSabran. Jakarta: Erlangga.

Kotler, Philip \& Garry Amstrong. 2006. Principles of Marketing. 11th Edition. Pearson International Edition. New Jersey: Prentice Hall.

Kotler, Philip dan Kevin Lane Keller. 2008. Manajemen Pemasaran (Edisi Kedua Belas). Cetakan Ketiga. Jakarta: PT. Indeks.

Kotler, Philip. 2000. Marketing Management. The Millenium Edition. New Jersey: Prentice Hall International, Inc.

Kotler, Philip. 2002. Manajemen Pemasaran. Jakarta: PT. Prenhalindo.

Kotler, Philip. 2008. Prinsip-Prinsip Pemasaran. Edisi Keduabelas, Jakarta: Prenhallinda.

Kotler, Philip. 1993. Manajemen Pemasaran. Jilid 2. Edisi keenam. Jakarta: Erlangga.

Kotler, Philip. 1994. Manajemen Pemasaran (Analisis, Perencanaan, Implementasi dan Pengendalian). Jakarta: Erlangga.

Lamb, ed al. 2001. Pemasaran (Marketing). Jakarta: SalembaEmpat 
Peter, J Paul., and Olson., Jerry C,. 2000. Consumer Behavior: Perilaku Konsumen dan Strategi Pemasaran. Terjemahan Damos Sihombing. Jilid 1.Edisi 4. Jakarta: Erlangga.

Robbins, Stephen P. 2007. Organizational behavior. 11 th edition. Pearson Prentice Hall, New jersey.

Sugiyono.2009. Metode Penelitian Kualitatif dan Kuantitatif. Bandung: Alfabeta.

Sutisnadan Prawita.2001. perilaku konsumen dan komunikasi. Bandung: PT. Remaja Rosda karya.

\section{SumberJurnal :}

Caruana, A. 2002. "Service Loyalty The Effects of Service Quality and The Mediating Role of Customer Satisfaction". European Journal of Marketing,36.

Lempoy, Nicklouse Christian; Silvya L. Mandey; danSjendry S.R. Loindong. 2015. "PengaruhHarga, Lokasi, Dan FasilitasTerhadapKeputusanMenggunakanJasa Taman WisataToarLumimuut (Taman Eman) Sonder”. Jurnal EMBA Vol.3 No.1 Maret 2015, Hal.10721083.

Mahfooz, Yasser. 2014. "Relationship between Service Quality and Customer Satisfaction in Hypermarkets of Saudi Arabia". International Jurnal of Marketing Studies, Vol 6 No 4. 2014.

Nugroho, Marno dan Ratih Paramita. 2009. “Analisis Pengaruh Lokasi, Keanekaragaman Barang Terhadap Keputusan Berbelanja dan Loyalitas Konsumen di Carrefour Semarang”, Jurnal Ekonomi dan Bisnis, Januari, Vol. 10 , No.

Tung, Gu-Shin dan Chiung-JuKuo. 2011. "Promotion, Swicthing Barriers and Loyalty. Australian Journal of Business and Management Research Vol,1 No,2.

Upadhana, Ida Bagus Ary. 2014. "Pengaruh Atmosfir Toko, Kualitas Pelayanan, Kelengkapan Barang dan Kewajaran Harga Terhadap Niat Beli Konsumen Pada Toko Painluva Seminyak Bali". E-Jurnal Manajemen Universitas Udayana Vol 3, No 5 (2014).Hal.1241-1256. 